\title{
Protist
}

August 2014, Volume 165, Issue 4, Pages 417-444

http://dx.doi.org/10.1016/i.protis.2014.04.004

(c) 2014 Elsevier $\mathrm{GmbH}$. All rights reserved.

\section{Morphological and Molecular Characterisation of Three New Azadinium Species (Amphidomataceae, Dinophyceae) from the Irminger Sea}

\author{
Urban Tillmann ${ }^{\mathrm{a}, *}$, Marc Gottschling ${ }^{\mathrm{b}}$, Elisabeth Nézan ${ }^{\mathrm{c}}$, Bernd Krock $^{\mathrm{a}}$, Gwenaël Bilien ${ }^{\mathrm{c}}$
}

\author{
${ }^{\text {a }}$ Alfred Wegener Institute, Am Handelshafen 12, D-27570 Bremerhaven, Germany \\ b Department Biologie, Systematische Botanik und Mykologie, GeoBio-Center, Ludwig- Maximilians-Universität \\ München, Menzinger Str. 67, D-80638 München, Germany \\ ${ }^{c}$ IFREMER, Station de Biologie Marine, Place de la Croix, BP 40537, 29185 CONCARNEAU Cedex, France \\ *: Corresponding author : Urban Tillmann, fax +49 47148311425 ; email address : Urban.Tillmann@awi.de
}

\begin{abstract}
:
Some species of the planktonic dinoflagellate genus Azadinium produce azaspiracids (AZAs), a group of lipophilic phycotoxins causing human poisoning after mussel consumption. We describe three new species from the North Atlantic, all of which shared the same Kofoidean plate pattern characteristic for Azadinium o $\mathrm{p}$ Azadinium trinitatum sp. nov. was mainly characterized by the presence of an antapical spine and by the position of the ventral pore at the left distal end of the pore $\mathrm{pl}$ te in $\mathrm{v}$ ity of I te 1 I t e 1 Azadinium cuneatum sp. nov. had a conspicuously formed first apical plate, which was asymmetrically elongated and tapered on its left lateral side with a ventral pore lo te $\mathrm{d} t$ the tip of this elong ted $1 \mathrm{pl}$ te Azadinium concinnum sp. nov. was of particular small size $(<10 \mu \mathrm{m})$ and characterized by an anteriorly elongated anterior sulcal plate and by large and symmetri pre ingul $r$ pltes The ventr I pore ws lo te $d$ inside the $\mathrm{pi}$ I pore $\mathrm{pl}$ te on the ells' right lateral side. Molecular phylogenetics as inferred from concatenated SSU rDNA, ITS, and LSU rDNA sequence data supported the distinctiveness of the three new species. None of the new species produced any known AZAs in measurable amounts.
\end{abstract}

Keywords : Azadinium ; Azaspiracids ; Irminger Sea ; Island ; new species. 


\section{1}

2

3 A large number of marine biotoxins produced by micro algae are known to accumulate in

4 shellfish making it harmful for human consumption. Intoxications have been categorized

5 based on diagnostic symptoms as Paralytic, Amnesic, Diarrhetic, and Neurotoxic Shellfish

6 Poisoning (PSP, ASP, DSP, NSP). As a fifth category, Azaspiracid Shellfish Poisoning (AZP)

7 was recently coined to account for a toxic syndrome associated with the consumption of

8 animals contaminated with azaspiracid toxins. The history of azaspiracids (AZAs) extends

9 back to November 1995, when a harvest of blue mussels cultivated in Killary Harbour (Ireland) was implicated in the poisoning of at least eight people in the Netherlands. Three years later, the causative toxin was isolated from mussels, identified, structurally defined and named azaspiracid according to its chemical characteristics (Satake et al. 1998). The AZAproducing organism, however, remained unknown until the isolation and identification of Azadinium spinosum Elbrächter et Tillmann from the North Sea (Tillmann et al. 2009) as a new species in a newly erected genus.

Considering the short interval since the first identification of Azadinium, the knowledge about its diversity has rapidly increased. The currently encountered seven species are the type species A. spinosum (Tillmann et al. 2009) and further A. obesum Tillmann et Elbrächter (Tillmann et al. 2010), A. poporum Tillmann et Elbrächter (Tillmann et al. 2011), A. polongum Tillmann (Tillmann et al. 2012b), A. caudatum (Halldal) Nézan et Chomérat [(Nézan et al. 2012); occurring in two distinct varieties: A. caudatum var. margalefii (Rampi) Nézan et Chomérat and A. caudatum var. caudatum], A. dexteroporum Percopo et Zingone (Percopo et al. 2013), and A. dalianense Z.Luo, H.Gu et Tillmann (Luo et al. 2013). Moreover, a close relative was identified with the description of Amphidoma languida Tillmann, Salas et Elbrächter, and Azadinium and Amphidoma were subsequently placed in the family Amphidomataceae (Tillmann et al. 2012a). 
Cells of Amphidoma and Azadinium are generally small and rather inconspicuous in

2 light microscopy. Determination of diagnostic morphological characteristics, such as

3 presence/absence of an antapical spine and distinct pyrenoid(s), or the location of a ventral

4 pore, requires electron microscopy or tedious high resolution light microscopy (Tillmann et

5 al. 2009, 2010, 2012, 2012b). Reliable identification of fixed cells of Azadinium from field

6 samples is thus problematic and is further challenged by similar size and shape in comparison

7 to a number of small species of Heterocapsa F. Stein. However, there is a need to

8 unambiguously identify and quantify the toxigenic source organisms of AZAs and to

9 distinguish these from their non-toxigenic relatives. This task is challenging because AZA-

producing and non-toxigenic species are known to co-exist in the same water mass (Tillmann

11 et al. 2010, 2011, 2012b).

Multiple strains of the type species A. spinosum, collected at different localities,

consistently produce AZA-1, AZA-2, and AZA-33 (an AZA with the molecular mass of 715;

Tillmann et al. 2012b). Other species have initially been described as non-toxigenic, as none of the known AZAs have been identified (Tillmann et al. 2010, 2011). However, the recent detection of four new AZAs in species such as A. languida and A. poporum indicates that species diversity within the Amphidomataceae is also reflected by high chemical diversity (Krock et al. 2012). Molecular probes for the first three described species (A. spinosum, A. obesum, A. poporum) are now available (Toebe et al. 2013) and are in the stage of being tested in field application (Tillmann et al. 2014a).

It cannot be excluded, or it is even to be expected, that there are more yet undescribed species of the Amphidomataceae. These may either include a yet not recorded primary source of AZAs, or might yield false-positive (if non-toxigenic) signals with the molecular probes already designed for toxigenic $A$. spinosum and A. poporum. It is therefore important to gain more information on the diversity of species present in the Amphidomataceae, on their molecular signatures, and on their geographical distribution. Both the widespread records of 
1 AZA toxins (Braña Magdalena et al. 2003; James et al. 2002; López-Rivera et al. 2009; Taleb

2 et al. 2006; Yao et al. 2010) and the increasing number of records of species of Azadinium

3 (Akselman and Negri 2012; Gu et al. 2013b; Hernández-Becerril et al. 2012; Percopo et al

4 2014; Potvin et al. 2012; Salas et al. 2011) indicate a global distribution of the genus.

5 However, species of Azadinium and/or the presence of azaspiracid toxins have not yet been

6 reported for arctic or subarctic areas (Poulin et al. 2011). In the present paper, we present

7 detailed morphological descriptions and sequence data of three new species of Azadinium

8 isolated from water samples collected in the North Atlantic between Greenland and Island.

9

10

11

12 


\section{Results}

2

3 Species Descriptions

4 Specimens of Azadinium were observed in concentrated whole water samples at a number of

5 stations between Greenland and Iceland and around the north-west coast of Iceland (Fig. 1). A

6 total of seven different strains were established. Two strains identified as Amphidoma

7 languida (isolated from station 532) and Azadinium dexteroporum (isolated from station 526,

8 see Fig. 1) will be presented elsewhere. The other strains were identified to represent three

9 different new species with three strains (4A8, 4B11, A2D11) of Azadinium trinitatum sp. nov, and one strain each for A. cuneatum sp. nov. (3D6) and A. concinnum sp. nov. (1C6) (Table

11 1).

12

Azadinium trinitatum Tillmann et Nézan, sp. nov. (Figs 2-6)

14

HOLOTYPE: SEM-stub CEDiT2014H41, prepared from strain A2D11, Figs. 3 B-D, 5C, E, I, 6E; interpretative figure (ICN Art. 44.2.): Fig. 4.

17 The strain A2D11 of A.trinitatum has been deposited at SCCAP, strain nr K-1883. ISOTYPE: Formalin fixed sample CEDiT2014I42, prepared from strain A2D11. TYPE LOCALITY: North Atlantic Ocean, off Iceland, 64 43.00’ N, 240 01.50’ W HABITAT: marine plankton, sub-Arctic ETYMOLOGY: The epithet is derived from the Latin term "trinitas" = triad, trinity. This was inspired by the fact that the species was available as three different clonal strains, and combine morphological characters of the first three described species of Azadinium, A. region), and $A$. poporum (the approximate position of the ventral pore). 
The following descriptions and micrographs were compiled from studying all three

2 strains (4A8, 4B11, A2D11), which were indistinguishable with respect to all morphological

3 details identifiable in light and electron microscopy. Cells of A. trinitatum were ovoid and

4 dorso-ventrally compressed. Freshly formalin preserved cells of strain A2D11 ranged from

5 11.3-16.6 $\mu \mathrm{m}$ in length (mean length: $14.1 \pm 0.8 \mu \mathrm{m}, \mathrm{n}=120$ ) and 7.1-11.5 $\mu \mathrm{m}$ in width

6 (mean width $9.2 \pm 0.8 \mu \mathrm{m}, \mathrm{n}=120$ ), with a mean length/width ratio of 1.5 . The episome,

7 which was higher than the hyposome, terminated in a conspicuous apical pore complex (APC)

8 (Fig. 2). The hyposome was rounded, slightly asymmetrical, and having its largest part

9 slightly shifted to the cells' right lateral side. A small antapical spine was visible in LM occasionally (Fig. 2 B-C). The cingulum was descending counter-clockwise, displaced by about the half of its width. It was deeply excavated and wide (1.8-2.4 $\mu \mathrm{m})$, occupying about one quarter of the cell length.

A presumably single chloroplast was parietally arranged, lobed, and exhibited bandshaped connections extending into the epi- and hyposome (Fig. 2 B-D, H-K). Generally, one large pyrenoid with a starch sheath (visible as a ring-like structure) was located in the episome (Fig. 2 A-C, E). Whereas the pyrenoid was always located in the epicone, the shape and number was found to be slightly variable (Fig. 2 F-G). For strain 4A8, a careful examination of 610 cells prepared from a substrain grown at $15{ }^{\circ} \mathrm{C}$ yielded 582 cells with a single pyrenoid and 28 cells with two pyrenoids. Among 615 cells inspected for strain A2D11, a single pyrenoid was seen in 539 cells, whereas two pyrenoids were detected in 76 cells. In a substrain of 4B11, the amount of cells with two pyrenoids was higher (114 of 600 cells). For all these observations, the presence of two pyrenoids was not related to cells prior to (as potentially indicated by an enlarged cell width) or during cell division. In addition to pyrenoid(s), cells may have a number of large grains both in the epi- and hyposome, which differed from pyrenoids in the absence of a clear starch shield covering them (Fig. 2 E). The 
1 large nucleus was spherical, ovoid through distinctly elongated and was located in the

2 hyposome (Fig. $2 \mathrm{H}-\mathrm{K})$.

3 Thecal plates of $A$. trinitatum were stainable and were identified with calcofluor white

4 (Fig. 2 L). However, the complete plate pattern was more easily determined by SEM (Figs 3,

5 5-6). The basic thecal plate arrangement was: Po, cp, X, 4', 3a, 6", 6C, 5S, 6"', 2"'” (Fig. 4).

6 The four apical plates were relatively small. Plate 1' showed an ortho-pattern and was slender

7 and almost symmetrical with small sutures to plates $2^{\prime}$ and $4^{\prime}$. In its posterior part, $1^{\prime}$ was

8 narrow with sutures running almost parallel to the sulcal area (Figs 3 A-C, 5 A, C).

9 Comparing the small lateral apical plates $2^{\prime}$ and $4^{\prime}$, the right plate $4^{\prime}$ was slightly larger and extending more to the right lateral side (Fig. 5 A-F). Dorsal apical plate 3' was hexagonal, small, and with slightly variable length of the suture to the intercalary plate 2a (Fig. 5 A, B, D-F). Of the three intercalary plates, the left (1a) and right (3a) plates were relatively large. Due to the small size of the apical plates, they almost reached the pore plate anteriorly. The mid intercalary plate 2a was small and tetragonal. Generally, it was longer than wide, but the shape was variable among cells. The six precingular plates were roughly similar in size, with plate $1^{\prime \prime}$ as the widest and plates $2^{\prime \prime}$ and 4 " as the narrowest. Plate $1^{\prime \prime}$ was in contact with an intercalary plate (1a) and thus in contact with four epithecal plates, whereas plate 6" was separated from plate 3a by the apical plate 4’ (Fig. 5 A-B).

The apical pore was rounded through ellipsoid (mean width: $0.56 \pm 0.04 \mu \mathrm{m}$, mean length: $0.66 \pm 0.06 \mu \mathrm{m}, \mathrm{n}=10$, size measurements using SEM images), located in the middle of the pore plate (Po), and covered by a cover pate (cp) (Fig. 5 G-I). A conspicuous rim bordered the dorsal and lateral margins of the pore plate adjacent to apical plates 2', 3', and 4', but was lacking ventrally, where the pore plate abutted the first apical plate and the Xplate. The apical pore was connected through a finger-like protrusion to the small X plate, which deeply invaded the first apical plate (1') with its posterior part. Shape and anterior 26 borderline of the X-plate could be seen from interior views of the cell (Fig. 5 I). As a 
1 conspicuous part of the apical pore complex, a large (mean outer diameter: $0.31 \pm 0.03 \mu \mathrm{m}, \mathrm{n}$

$2=12$ ) and distinct pore, designated as ventral pore (vp), was located at the left lateral side of

3 the pore plate. This pore mainly laid within a pocket of the first apical plate and contacted the

$4 \quad 2^{\prime}$ plate and the pore plate (Fig. 5 G-H).

The hypotheca consisted of six postcingular and two antapical plates (Fig. 6 A-B). All postcingular plates were tetragonal and similar in shape, but slightly variable in size. Of the two antapical plates, the 2 "'” plate was distinctly larger with an oblique running suture to plate $1^{\prime \prime \prime}$, which was slightly more anterior in position (Fig. 6 A-B). A short spine could be detected on the second antapical plate (Fig. 6 A-C).

The cingulum was wide, descending, and displaced by about half of its width. Narrow cingular lists were present. The cingulum was composed of six comparably sized plates, except for plate C6 that was more slender than the others (Fig. 6 C-D). Furthermore, this plate was asymmetric in shape, with a conspicuous extension partly covering the sulcal area and thus giving the flagellar pore area a comma-shaped appearance.

The deeply concave sulcus (Fig. 6 C, E) consisted of a large anterior sulcal plate (Sa) that with a broad to slightly pointed anterior side partly invaded the epitheca, and a large posterior sulcal plate (Sp), that extended two-thirds of the line from the cingulum to the antapex. The left sulcal plate (Ss) was broad, located anterior to Sp and abutted plates $1^{\prime \prime \prime}$, C1, Sa, Sd, Sm, Sp, and C6. The right sulcal plate (Sd) abutted sulcal plates Ss and Sm, as well as cingular plate C6. The median sulcal plate (Sm) contacted sulcal plates Sa, Ss and Sd (Fig. 6 E-F). These plates had apparently complex three-dimensional morphologies, with large flanges invading into the hypotheca (Fig. 6 F).

The surface of all thecal plates was smooth but irregularly covered by few pores of different size (e.g. arrows in Fig. 5 B). Larger pores ranged in size from 0.11-0.14 $\mu$ m (mean $0.12 \pm 0.01, \mathrm{n}=14$ ), whereas the outer diameter of small pores ranged from 0.07-0.09 $\mu \mathrm{m}$ (mean $0.08 \pm 0.01 \mu \mathrm{m}, \mathrm{n}=12$ ). Pores were particularly abundant on the apical plates and 
1 most numerous on the large intercalary plates, whereas plate 2a invariably was free of pores

2 (Fig. 5). Both pre- and postcingular plates only had few pores. On postcingular plates these

3 were mainly located close to the cingulum (Fig. 6 A). Occasionally, small pores were found in

4 small clusters occurring mainly on the cingular plates (Fig. 6 F). There were only few pores

5 on the antapical plates, mainly located around the antapical spine (Fig. 6 A). In sulcal plates, a

6 row of pores was typically present on the left anterior part of Sa (Fig. 6 E-F), although it was

7 often was difficult to observe. A small group of pores was located both on lateral sides of Sp

8 and in the middle of Ss, whereas the small sulcal plate Sm and Sd were free of pores.

9 The characteristic overlapping pattern of thecal plate margins, individually identified

for each suture mainly by available interior views of the theca (not shown), is indicated in Figure 4 C-D. In the epitheca, the most ventral plate $1^{\prime}$ was overlapped by all adjacent plates except for the pore plate, whereas the almost mid-dorsal precingular plate 3" was identified as the "keystone plate” (i.e., a plate overlapping all its neighbours: Fig. 4 C). Within the apical series, the dorsal plate $3^{\prime}$ was overlapped by both adjacent apical plates $2^{\prime}$ and $4^{\prime}$. The small median intercalary plate 2a was overlapped by all adjacent plates. In the cingular and postcingular series, we identified plates C3 and 4"' as keystone plates, respectively (Fig. 4 D). On the right-ventral side, the last cingular plate C6 was overlapped not only by the C5 plate but also by the anterior sulcal plate (Sa) (Figs 4 C, 6 F).

In our strains, a number of deviations from the typical plate pattern shown in Figure 4 were observed (Supplementary Material Figs S1 and S2). Variations in plate pattern primarily consisted of additional sutures between the epithecal plates (Supplementary Material Fig. S1 A-I), although variation in number of hypothecal plates were also observed (Supplementary Material Fig. S1 J-L). As a rare exception, a penta-configuration of plate 2a was observed (Supplementary Material Fig. S2 A). The shape of plate 1' was variable and was very slender in its proximal part occasionally (Supplementary Material Fig. S2 B-C). Although not explicitly quantified, a significant number of specimens had a very short or rudimentary spine, 
1 or a spine was completely lacking (Supplementary Material Fig. S2 D-I). The position of the

2 ventral pore was consistent but among hundreds of inspected cells, four exception were found

3 nevertheless, in which the pore was displaced posteriorly (Supplementary Material Fig. S2 J-

$4 \mathrm{M})$.

5

6

$7 \quad$ Azadinium cuneatum Tillmann et Nézan, sp. nov. (Figs 7-12)

8

9 HOLOTYPE: SEM-stub CEDiT2014H43, prepared from strain 3D6; Figs 8 A-D, 10 B-E, 11

D, 12 C-D; interpretative figure (ICN Art. 44.2.): Fig. 9.

11 The strain 3D6 of A. cuneatum has been deposited at SCCAP, strain nr K-1882.

ISOTYPE: Formalin fixed sample CEDiT2014I44, prepared from strain 3D6.

TYPE LOCALITY: North Atlantic Ocean, off Iceland, 65²7.00’ N, 24 39.00’ W

14

15

16

17

18

19

20

21

22

23

24

25

26

HABITAT: marine plankton, sub-Arctic

ETYMOLOGY: The epithet is inspired by the distinct shape of the first apical plate, which is wedge-shaped in its distal part (lat.: cuneatus = wedge-shaped).

Cells of A. cuneatum were ovoid and slightly dorso-ventrally compressed. Cell size of freshly formalin preserved cells ranged from 11.2-16.9 $\mu \mathrm{m}$ in length (mean $14.2 \pm 1.0, \mathrm{n}=$ 188) and from 8.3-12.7 $\mu \mathrm{m}$ in width (mean $10.8 \pm 1.0, \mathrm{n}=188$ ), with a mean length/width ration of 1.3. The episome was higher than the hyposome, and it terminated in a conspicuous apical pore complex of a concave shape (Fig. 7). The generally rounded hyposome could be flattened and generally was slightly asymmetric with the longest part displaced to the cells’ right lateral side. The subequatorial located cingulum was broad and conspicuous in LM (Fig. 7 B, G, I). A presumably single chloroplast was parietally arranged, lobed, retiform in the episome, and extending into the epi- and hyposome (Fig. 7 D, H, J-K). A large pyrenoid with 
1 a starch sheath (visible as a ring-like structure) was predominantly located in the episome

2 (Fig. 7 D, G, I). However, there was some variability for both the number and position of 3 pyrenoid(s) (Fig. 7 E-F). Among 611 cells of a culture grown at $15^{\circ} \mathrm{C}, 573$ cells had a single

4 pyrenoid located in the episome, 19 cells had a single pyrenoid located in the hyposome, 6

5 cells had a single pyrenoid located in the cingular area, 11 cells had two pyrenoids both

6 located in the episome, and two cells had two pyrenoids, one of which was located in the

7 episome and one in the hyposome. For another strain grown at $10^{\circ} \mathrm{C}$, a comparable

8 quantification of 621 cells yielded 577 cells with a single pyrenoid in the episome, 22 cells

9 with a single pyrenoid located in the hyposome, and 22 cells with two pyrenoids, all of them located in the episome. The large nucleus was located in the hyposome/cingular region and typically was spherical through ovoid, but elongated nuclei extending into the episome could also be observed (Fig. 7 H, J).

SEM analysis of $A$. cuneatum (Figs 8-12) revealed the basic thecal plate patter as Po, cp, X, 4', 3a, 6"', 6C, 5S, 6"”, 2"'” (Fig. 9). Among the 4 apical plates, the lateral and dorsal plate 2', 3', and 4' were relatively large and of equal size (Fig. $10 \mathrm{~A}-\mathrm{B}$ ). The lateral apical plates 2'and 4' largely extended into the ventral area accounting for about half of the epitheca's height (Fig. 10 C-D). The first apical plate was rhomboid and almost symmetric in its posterior part, but was distinctly asymmetric in its anterior part, which was unequally elongated and tapered on its left side reducing the pore plate. Three intercalary plates were symmetrically arranged on the dorsal side (Fig. 10 A, E-F). As the most abundant arrangement, the distinctly smaller central intercalary plate 2a was tetragonal and almost symmetrically located above plate 3" (Fig. 10 E), but with a slight displacement to the cells’ right lateral side. A penta-configuration (i.e., plate 2a was pentagonal) was abundant, but with plate $2 \mathrm{a}$ in contact to $3^{\prime \prime}$ and $4{ }^{\prime \prime}$ and with the suture between $3 "$ and $4 "$ shifted towards the dorsal centre (Fig. 10 F). In cells of a single preservation step, 84 of 123 specimens had a tetragonal 2a, whereas the plate had a penta-configuration in 39 specimens. In cells of another 
1 preservation step, plate 2a was tetragonal in 27 and pentagonal in 18 of 45 specimens,

2 respectively. The first and last of the six precingular plates were restricted to the ventral area

3 and distinctly separated from (i.e., not in contact to) the dorsal intercalary plates (Fig. 10 A-

4 D). Plates 6" and 4" were the narrowest precingular plates, while plate 2" was the widest

5 (Fig. $10 \mathrm{~A})$.

The distinct apical pore was circular, tear-drop shaped, or slightly ellipsoid with a

mean width of $0.69 \pm 0.04 \mu \mathrm{m}(\mathrm{n}=12)$ and a mean length of $0.85 \pm 0.04 \mu \mathrm{m}(\mathrm{n}=10)$. It was

8 located in the dorsal part of a slightly elongated pore plate and covered by a cover plate (Figs

910 A-B, 11 A-F). Because of the invading tip of plate 1', the pore plate was distinctly asymmetric. It was bordered by a rim formed by the apical plates along the sutures of $2^{\prime}-4^{\prime}$ and the pore plate. Rarely, the rim extended along the left lateral side between the suture of plate $1^{\prime}$ and 2' (Fig. $11 \mathrm{E}$ ). An X plate was located between the first apical and the pore plate, which was clearly visible from interior views as a small and slightly elongated plate. It invaded both the pore plate and the $1^{\prime}$ plate, but without reaching the apical pore (Fig. $11 \mathrm{~F}$ ), as it might be the impression from exterior view. Cover plate and X-plate were connected by a characteristic finger-like protrusion (Fig. 11 A-E). A distinct pore with a mean outer diameter of $0.33 \pm 0.02 \mu \mathrm{m}(\mathrm{n}=12)$ was located on the left lateral side of the pore plate and at the tip of the elongated left anterior part of the first apical plate on the suture between the pore plate and the apical plate 2' (Fig. 11 A-E). Despite its almost apical position, we denominate this pore as the "ventral pore” (vp). the six postcingular plates, plate 5"' was the widest. Plates $1^{\prime \prime \prime}$ and 6 "' were in ventral position and of the same small size as the most dorsal plate $4{ }^{\prime \prime \prime}$. Plate $3^{\prime \prime \prime}$ was the plate of the postcingular series in contact to both antapical plates. Of the two antapical plate, plate 2"'” was about double the size of the $1^{\prime \prime \prime \prime}$ plate (Fig. 12 A-B). 
The subequatorial cingulum was wide, descending, displaced by about half of its

2 width, and was composed of six plates (Fig. 12 C). It exhibited narrow cingular lists formed

3 by the posterior margins of the precingular plates and anterior margins of the postcingular

4 plates (Fig. 8 A-D). The most dorsally located C3 and the lateral cingular plates C2 and C4

5 were wide and the ventrally located last cingular plate C6 forming the right ending of the

6 sulcal area was the narrowest cingular plate (Fig. 12 C).

The excavated sulcal area was formed by five plates (Fig. 12 D-E). The large anterior

8 sulcal plate (Sa) partly invaded the epitheca, and the large posteriour sulcal plate (Sp)

9 extended about half the line from the central sulcus to the antapex (Fig. 8 A-B). The left sulcal plate (Ss) was very broad and ran along the line from plate C1 to C6. Two smaller and centrally located sulcal plates (Sm and Sd) formed a concave central pocket (Fig. 12 D-E). The plates of A. cuneatum were smooth with irregularly distributed small pores (Fig. 8) of slightly varying size (range: 0.08-0.14 $\mu \mathrm{m}$; mean: $0.11 \pm 0.02 \mu \mathrm{m}, \mathrm{n}=23$ ). On the epitheca, pores were concentrated on the anterior area of the apical plates (Fig. 10). The median intercalary plate 2a was consistently free of pores. Generally, pores were individual or arranged in small groups of up to eight. On both post- and precingular plates, pores were arranged along the boundary to the cingulum (Figs $12 \mathrm{~A}, 10 \mathrm{E}$ ). Small groups of pores were present on sulcal plates Sa, on both lateral sides of Sp, and as a distinct group of pores located in the middle of the broad Ss plate (Fig. 8 A-B).

The pattern of plate overlap was identified individually for each suture mainly by interior view (not shown) and is depicted in Figure 9 C-D. As most characteristic features, 22 plate $3^{\prime}$ was overlapped by its neighbouring apical pates $2^{\prime}$ and $4^{\prime}$, plate 2a was overlapped by 23 all adjacent plates, and plate C6 was overlapped by the central sulcal plate Sa. As keystone 24 plates of A. cuneatum, we identified 3"', C3 and 4"' for the precingular, the cingular, and the 25 postcingular series, respectively. 
Plate variability observed in the culture of A. cuneatum mainly occurred in the

2 epitheca. The presence of both quadra- and penta-configuration of plate 2a (Supplementary

3 Material Fig. S3 A-C) was already described before. In addition, only two intercalary plates

4 may rarely be present (8 out of 131 cells) (Supplementary Material Fig. S3 D-I). Other

5 epithecal variants and a hypothecal reduction of postgingular plates are illustrated in

6 Supplementary Figure S4 A-E. The position of the ventral pore for A. cuneatum was

7 consistent but among hundreds of investigated cells, four exceptions were found nevertheless,

8 where the pore - together with varying degrees of a reduction of the anterior elongation of

9 plate $1^{\prime}$ - was displaced posteriorly (Supplementary Material Fig. S4 F-I).

Azadinium concinnum Tillmann et Nézan sp. nov. (Figs. 13-17)

HOLOTYPE: SEM-stub CEDiT2014H45, prepared from strain 1C6; Fig. 14 A-B; interpretative figure (ICN Art. 442.): Fig. 15.

The strain 1C6 of A. concinnum has been deposited at SCCAP, strain nr K-1881.

ISOTYPE: Formalin fixed sample CEDiT2014I46, prepared from strain 1 C6.

TYPE LOCALITY: North Atlantic Ocean, Irminger Sea, off Greenland, 62 $13.95^{\prime}$ N, $37^{\circ}$

HABITAT: marine plankton, sub-Arctic

ETYMOLOGY: The Latin adjective “concinnus” (= beautiful, elegant, harmonious, "skilfully put together”) reflects the concinnity of this delicate and petite species.

Cells of A. concinnum were very small, slender and only slightly dorso-ventrally 
1 terminated in a conspicuous antapical spine in median or laterally displaced position (Fig. 13

2 B-E). The cingulum was very broad and deeply excavated. Cell size was 8.0-11.5 $\mu \mathrm{m}$ in

3 length (mean $=9.5 \pm 0.7, \mathrm{n}=175)$ and 5.6-8.3 $\mu \mathrm{m}$ in width (mean $=6.6 \pm 0.5, \mathrm{n}=175$ ),

4 resulting in a mean length/width ration of 1.4. A presumably single chloroplast was present,

5 which was lobed and extending from the episome into the hyposome (Fig. 13 F-I). In LM,

6 there was no indication for the presence of a pyrenoid surrounded by a starch shield.

7 Occasionally, a number of spherical bodies of varying size was seen in both the epi- and

8 hyposome (Fig. 13 D-F). A large and almost spherical nucleus was located in the

9 subequatorial cingular region (Fig. $13 \mathrm{G}, \mathrm{I}$ ).

Thecal plates of A. concinnum probably were weakly developed and delicate, which

11 made it almost impossible to obtain complete cell views of trim specimens. The basic plate pattern of $A$. concinnum as inferred from SEM images (Figs 14-17) was Po, cp, X, 4', 3a, 6", 6C, 5S, 6"', 2"'” (Fig. 15). Four small apical plates surrounded the apical pore (Fig. 16). The first apical plate, which was extending half the line from the apex to the cingulum (Fig. 14 A), 15 was narrow, showed sutures to the apical plates 2' (shorter) and 4' (longer) of slightly unequal length (Fig. 16 B), and was rectangular in its posterior part (Fig. 16 A). The sutures of plate 3' to its neighboring apical plates were very short so that the epithecal intercalary plates almost approached the pore plate (Fig. 16 A, D). The series of three small intercalary plates were located dorsally and together formed an almost circular area with the apical plates around the apical pore. Plate 2a was distinctly smaller than the other intercalary plates and was of pentagonal shape and symmetrically in contact to two precingular plates. All six precingular plates were of equal size and were arranged symmetrically with the suture between plate 3 "' and $4 "$ in mid-dorsal position.

An upward arched arrangement of the apical plates gave rise to the distinct and 
1 covered by a cover plate, and centrally located in a horseshoe shaped pore plate (Fig. 16 A, H-

2 I). At its lateral and dorsal parts, a thick rim bordering the pore plate extended ventrally along

3 the sutures of plate $1^{\prime}$ with its adjacent apical plate 2' and 4' (Fig. 16). A small and circular

4 X-plate was visible from interior views (Fig. 16 I), which did not invade the first apical plate

5 and which was shifted to the cells' right lateral side adjacent to the ventral pore (see below).

6 A finger-like protrusion connecting the X-plate and the cover plate was characteristically

7 bended to the cells' right lateral side inserting at the cover plate in a subequatorial position

8 (Fig. $16 \mathrm{G}-\mathrm{H}$ ). A distinct "ventral pore” was located on the right ventral side of the pore plate

9 with a distortion of the suture Po/4', the latter one characteristically accentuated by the recessed run of the rim (Fig. $16 \mathrm{G}-\mathrm{I})$.

The hypotheca was composed of six postcingular and two antapical plates (Fig. 17 A).

The first and the last postcingular plates were of similar size, ventrally located, and of distinctly lower height compared to the other postcingular plates. Plate 3 "' was in contact to both antapical plates. Because of the low height of the ventral postcingular plates, both antapical plates largely extended into the ventral area to almost the same level. Plate 2"'” was large and separated by a slightly oblique suture from the smaller first antapical plate. A distinct and approx. $0.95 \mu \mathrm{m}$ long antapical spine was located on the dorsal part of plate $2^{\prime \prime \prime}$ in the cells median axis or slightly displaced to the cells left lateral side (Fig. 14).

With a width of about 2-2.5 $\mu \mathrm{m}$, the cingulum of $A$. concinnum was remarkably wide accounting for about a quarter of total cell length. Furthermore, the cingulum was deeply excavated, slightly descending, and composed of six plates (Fig. 17). Of the five sulcal plates, the anterior sulcal plate Sa deeply invaded the epitheca with an elongated and tapered end reaching about half the line to the apex (Figs $14 \mathrm{~A}, 17 \mathrm{~B}, \mathrm{C}$ ). The plate Ss running from plate C1 across to plate C6 was broad on its left side but distinctly slender in its right part, which together with the small central sulcal plates Sd and Sm - formed a deeply concave and egg26 shaped central pocket (Fig. 17 B-D). 
The surface of thecal plates was smooth with just a very few though conspicuous pores

2 present (Fig. 14). Invariably, the postcingular plates had a single pore located at underlapping

3 margins (see below) of the suture to the neighboring postcingular plates (Fig. $17 \mathrm{~A}$ ).

4

Consequently, the keystone plate plate 4"' (see below) was free of pores.

5 Furthermore, pores were present on both epithecal and hypothecal margins of cingular plates

6 (Fig. 14). Lateral and dorsal apical plates $2^{\prime}-4^{\prime}$ were free of pores, as were all precingular

7 plates and the central intercalary plate 2a (Fig. 16). A single or rarely two or three pores were

8 located on the outer intercalary plates (Fig. 16 D). A characteristic vertical row of 3-5 pores

9 was always present on the first apical plate (Fig. 16 A-B, G-H).

The pattern of plate overlap of A. concinnum as inferred mainly from available interior

Molecular Results

views (not shown) is schematized in Figure 15 C-D. The overlap pattern was identical to the patterns described for A. trinitatum and A. cuneatum, with plates 3", C3, and 4"' identified as keystone plates of the precingular, cingular, and postcingular series, respectively.

Variation of plate pattern observed in the culture of $A$. concinnum are summarised in Supplementary Figures S5 and S6. Plate pattern variability was mainly observed for epithecal plates. The most frequently encountered deviations were a loss of one intercalary plate and/or displacement of intercalary plates providing contact to the pore plate. For A. concinnum, no variability in ventral pore position was observed among hundreds of cells investigated.

The SSU+ITS+LSU alignment was 4609 bp long and comprised 1813 parsimony informative sites (39\%, mean of 11.62 per OTU). Tree topologies were largely congruent, irrespectively whether the Bayesian or the ML algorithm was applied. Many nodes showed high if not maximal support values. Figure 18 shows the best-scoring ML tree, in which the Amphidomataceae were monophyletic (99LBS, 1.00BPP) with respect to the outgroup. The 
1 internal topology of the Amphidomataceae was not fully resolved, but showed a sister group

2 relationship between Amphidoma languida and Azadinium (55LBS). As inferred from very

3 short branches in the molecular tree, the different accessions of the three new species did not

4 show notable variation of rRNA copies.

The new species had different phylogenetic positions in the molecular tree: Azadinium concinnum (100LBS, 1.00BPP) constituted the sister species of the remainders of Azadinium (100LBS, 1.00BPP). Within Azadinium, a sister group relationship consisted between $A$. cuneatum (100LBS, 1.00BPP) and a clade comprising the species A. dalianense, A. obesum,

9 A. poporum, A. spinosum, and A. trinitatum (1.00BPP). Azadinium trinitatum had its closest relative in a yet undescribed symbiotic partner of the radiolarian Acanthochiasma Krohn, 1861 (94LBS, 1.00BPP) and together, they were closely related to a clade comprising A. dalianense, A. obesum, A. poporum, and A. spinosum.

AZA Analysis

Using SRM, none of previously described AZAs (AZA-1 to 12 and AZA-33 to -41) were found in A. concinnum (1C6), A. cuneatum (3D6), and A. trinitatum (4A8, 4B11, A2D11) at a detection limit of $1.1 \mathrm{pg}$ on column, which corresponds to a limit of detection at cellular level of 0.020-0.026 fg cell ${ }^{-1}$ for $A$. trinitatum (slightly different for the different strains due to different biomass of the samples), $0.015 \mathrm{fg} \mathrm{cell}^{-1}$ for $A$. cuneatum, and $0.012 \mathrm{fg} \mathrm{cell}^{-1}$ for $A$. concinnum. and $m / z 362$ of AZAs, precursor ion experiments were also negative for all three species. However, the precursor on mode is approximately a hundred times less sensitive than the SRM mode and strictly speaking, it did not allow for exact quantitative measurement. 


\section{Discussion}

2

3 Plate pattern analysis clearly shows that all strains reported here belong to the

4 Amphidomataceae in general and to Azadinium in particular. Moreover, our analysis reveals

5 unique morphological features justifying the description of three new species, and this has

6 been confirmed by the phylogenetic analysis based on concatenated sequence data of the

7 SSU, ITS, and LSU rDNA. Already with the description of the first Azadinium species, the

8 presence of an antapical spine and the position of a ventral pore have been highlighted as

9 important morphological features characterizing different species (Tillmann et al. 2009, 2010,

2011). With the present work and now distinguishing 10 species of Azadinium, this notion is

11 reinforced with the position of the ventral pore identified as one of the most distinctive

characters (Table 3). Generally, the position of the ventral pore seems to be a distinct and

species-specific character for species of Azadinium, although a deviating position of the

ventral pore can be found very rarely (Potvin et al. 2012; this study: Supplementary Material

15 Figs S2, S4). In particular, the three new species described here can be distinguished from other species of Azadinium by a number of features as follows:

\section{Azadinium trinitatum}

The main characteristic and distinctive features of $A$. trinitatum are the unique combination of the location of the ventral pore (located at the left distal end of the pore plate), the presence of three epithecal intercalary plates, and the presence of an antapical spine. As it is reflected in its name, $A$. trinitatum combines morphological characters of the first three described species of Azadinium. While sharing the presence of an antapical spine with A. spinosum, the slightly more obese cell shape, the distinctly slender posterior part of plate $1^{\prime}$, and the outline of the sulcal region more closely resembles $A$. obesum. With the third species, A. poporum, and also 
1 position of the ventral pore on the left side of the pore plate (Table 3). However, a detailed

2 comparison of the pore plate and vp arrangement (Fig. 19) indicates that the ventral pore is

3 located more in a cavity of the pore plate in A. poporum. For A. dalianense, the ventral pore is

4 located at the junction of the pore plate and the first two apical plates in a cavity mainly

5 formed by the second apical plate and the pore plate. The suture between Po and $1^{\prime}$ is almost

6 symmetric in A. dalianense. For A. poporum, the pore plate is slightly asymmetric: The left

7 side of the suture $\mathrm{Po} / 1^{\prime}$ with the vp is located closer to the apical pore than the right side. In

8 contrast, the ventral pore is located more in a cavity of the $1^{\prime}$ plate at the tip of an elongated

9 side of the pore plate in A. trinitatum. The pore plate is asymmetric but here, the left side of the suture Po/1' with the vp is more distant from the apical pore than the right side (Fig. 19).

11 The elongated left side of the Po plate resembles the asymmetric and elongated shape of the Po of A. dexteroporum (Percopo et al. 2013) but here, the elongated side of Po is at right.

The presence/absence and development (in case of A. caudatum vars margalefii or caudatum, respectively) of an antapical spine has also been emphasized in distinguishing species of Azadinium (Table 3). For all three strains of A. trinitatum, we identify a short antapical spine, but we find this trait to be variable. Indeed, the presence of a spine in our cultures is predominant, but such structure is rudimentarily present or definitely missing in many cells (see Supplementary Material Fig. S2 D-I). More prominent spines are described for $A$. spinosum, A. caudatum, A. polongum, A. dexteroporum, and described here for A. concinnum. A sporadic but significant presence of a more rudimentary spine is also described for $A$. dalianense (Luo et al. 2013). In any case, more targeted studies of cultivated material are needed to evaluate potential effects of culture conditions in Azadinium (not restricted to spine formation but also including clonal plate pattern variability). 
1 Later, Holmes (1956) reported from a "small Goniaulax probably identical with G. gracilis

2 Schiller” in the southern central Labrador Sea. We cannot exclude that his figure 28 (p. 61) is

3 a species of Azadinium and particularly A. trinitatum. However, the small spine at the antapex

4 is lacking in his illustration, while it is visible even using LM in A. trinitatum. Later, Bérard-

5 Therriault et al. (1999) provided additional figures of this species (pl. 90) showing dinophytes

6 with a great similarity to Azadinium in terms of size, shape, and outline of the sulcal area. One

7 of the specimens depicted therein has an antapical spine and another cell obviously has no

8 spine. Other details are not provided, so it even remains uncertain whether the dinophytes

9 they reported from eastern Canada in fact represent species of Azadinium. Nevertheless, it is

10 possible that they represent $A$. trinitatum based on the general appearance of these cells. The

11 similarity of the locality of the specimen depicted by Bérard-Therriault et al (1999), the

12 Canadian Arctic and our record of A. trinitatum from Iceland, generally would support this

13 view.

14

Azadinium cuneatum

16 A. cuneatum differs from all other species of Azadinium by a very particular first apical plate, which is asymmetrically elongated and tapered on its left lateral side reducing the pore plate. Differently from all other species of Azadinium, the ventral pore is located in the middle of the pore plate at the tip of the elongated $1^{\prime}$ plate and invading both Po and the second apical plate $2^{\prime}$. In addition, A. cuneatum is characterized by the exceptional large size of the apical

21 plates (Table 3). Furthermore, the first precinguar plate is not in contact with the first

22 intercalary plate, a feature that $A$. cuneatum is sharing with $A$. obesum and $A$. concinnum only

23 (Table 3).

24 A tetra-configuration of the intercalary plate 2a (i.e., plate 2a is tetragonal and in 25 contact with the $3^{\prime \prime}$ plate) is the most abundant configuration for A. cuneatum. However, a 26 penta-configuration (i.e., plate 2a in contact to five other plates, including both $3{ }^{\prime \prime}$ and $4{ }^{\prime \prime}$ ) is 
1 present in many cells as well. In most cases, contact of 2a to $3^{\prime \prime}$ and $4{ }^{\prime \prime}$ is asymmetric (a

2 wider suture of 2a and 3": Fig. 10 F), but an almost symmetric arrangement is also observed,

3 albeit rarely (Supplementary Material Fig. S3 C). A symmetric arrangement of precingular

4 plates and a penta-configuration of plate 2a have been described here for the new and first

5 branching species A. concinnum. The presence of both tetra- and penta-configuration of plate

6 2a within a single species has also been described for field populations of Peridiniella danica

7 (Paulsen) Okolodkov et J.D.Dodge (Okolodkov and Dodge 1995) although here,

8 conspecificity of the different types is not confirmed.

$9 \quad$ For many cells (in one preparation quantified as 6\%), the presence of only two intercalary plates is noted in A. cuneatum (Supplementary Material Fig. S3 D-I). If the absence of pores is indicative for the "true" 2a plate indicates that both possibilities, loss of

12 the first and loss of the last intercalary plate are likewise plausible. An consistent presence of only two intercalary plates has been described as the main character of A. dalianense, and

14 here in connection with a concurrent reduction of the apical series to three apical plates (Luo 15 et al. 2013).

Azadinium concinnum

Azadinium concinnum is unique among species of Azadinium by an elongated anterior sulcal plate ranging far into the epicone, by large und symmetric precingular plates, by very small apical and epithecal intercalary plates, and by having a penta-configuration of plate 2a as the most common configuration. Although size ranges of most species of Azadinium do overlap,

A. concinnum is of particularly small size, almost identical in size with the small species $A$. 
1 part of an elongated extension of the right side of the pore plate in A. dexteroporum (Percopo

2 et al. 2013). A position of the ventral pore on the cells' right lateral side is a feature shared by

3 A. concinnum with A. caudatum, A. dexteroporum, and Amphidoma languida. In terms of the

4 elongated Sa plate, the large and symmetric precingular plates and the small epithecal

5 intercalary plate with 2a in a penta configuration, there is another species having exactly such

6 features. A small dinophyte species has been described in 1959 as Gonyaulax parva Ramsfjell

7 from Atlantic Ocean samples of the central Norwegian Sea and from waters towards Iceland

8 (Ramsfjell 1959). The plate pattern of this species is, anyhow, different from Gonyaulax and

9 in fact corresponds to the plate tabulation of Azadinium. Subsequently, the species should be transferred to Azadinium (Tillmann et al. 2009), but this will be performed in a further taxonomic study. In any case, A. concinnum differs from G. parva by the presence of the antapical spine, by the smaller size, and by a more slender cell shape. Based both on the very similar features of the precingular plates (symmetrical arrangement and size), and on the small size of all apical and intercalary plates, we expect a very close relationship between $A$. concinnum and G. parva. Presence and/or position of the ventral pore have not been reported, because LM observations of G. parva only are available at this moment in time. The presence of six large and symmetrical precingular plates, and a small size of the remaining epithecal plates of $A$. concinnum, are features also typical for Amphidoma (Dodge and Saunders 1985; Tillmann et al. 2012a). Moreover, conspicuous pores are consistently located at the sutures of the postcingular plates of A. concinnum and A. languida as well. At a first glance, there is a large difference in epithecal plate arrangement, with Amphidoma

22 exhibiting six apical plates and no apical intercalary plate, while all species of Azadinium have only 3-4 apical plates but 2-3 apical intercalary plates. However, this difference vanishes when the total number of epithecal plates is considered: It is plausible to assume that the intercalary plates of Azadinium are homologous to at least some of the apical plates present in 
1 controversially in the past also for other dinophyte species such as Protoceratium reticulatum

2 (Clapérade et Lachmann) Buetschli [= Gonyaulax grindleyi P.Reinecke, Gonyaulacales;

3 Dodge (1989); Hansen et al. (1996/97)]. The taxon has been described with both 4', 0a

4 (Wołoszyńska 1928) and 3’, 1a (Reinecke 1967), respectively. Hansen et al. (1996/97)

5 likewise circumscribed the epithecal plate pattern of the species as 3', 1a, 6"', but emphasized

6 as well that nearly $50 \%$ of cells of a field sample show contact between 1 a and the pore plate

7 (i.e., 4', 0a, 6" in a strict Kofoidean formula).

8

$9 \quad$ Plate Overlap

All three new species share the same imbricate plate overlap pattern. Generally, plate overlap patterns may reflect functional aspects of ecdysis and/or archeopyle types of coccoid cells, and help to determine plate homologies. A number of uncommon imbrications have been identified for the genus Azadinium, i.e. the most dorsal apical plate 3 ' is overlapped by the adjacent apicals $2^{\prime}$ and $4^{\prime}$, the median intercalary plate $2 \mathrm{a}$ is overlapped by all adjacent plates, and the large anterior sulcal plate overlaps the last cingular plate C6 (Luo et al. 2013; Nézan et al. 2012; Tillmann and Elbrächter 2010; Tillmann et al. 2012a, 2012b), and all of these pattern have been confirmed here for the three new species.

Pyrenoids

22 For a number of species, stalked pyrenoid(s) are visible in LM because of a distinct starch 23 cup. The presence/absence, position, number, and ultrastructure of pyrenoids have been 24 regarded as useful characters to delimitate taxa (Schnepf and Elbrächter 1999; Tillmann et al. 25 2011) and has in particular been discussed as a powerful feature visible to differentiate 26 species of Azadinium in LM (Tillmann et al. 2011). A. concinnum consistently lacks 
1 pyrenoid(s) identifable by a distinct starch cup, but pyrenoid(s) are variable in A. trinitatum

2 (both number and position) and A. cuneatum (number). Variability in pyrenoid number and

3 position has also been reported for $A$. dalianense, indicating that these traits are of limited

4 value for species delimitation. In any case, more detailed information (including

5 ultrastructure) related to the pyrenoids of Azadinium is needed.

6

7 Evolution

8

9 The Amphidomtaceae are always retrieved monophyletic in molecular phylogenetic analyses

10 (Gu et al. 2013a; Tillmann et al. 2012a, 2012b), although the sister group has not be

11 determined reliably at this moment in time. This challenges the interpretation of character

12 evolution within the group. Therefore, it remains unresolved whether the epithecal plate pattern is derived either in Amphidoma (six apical plates, no intercalary plates) or in Azadinium (four apical plates, three intercalary plates), because outgroup comparison is not possible. Azadinium concinnum is the first branching species of Azadinium and shows some plate pattern variability, at least in our strain. A number of these variants can be interpreted either as loss of a single intercalary plate and/or as a displacement of a single intercalary plate getting in contact with the pore plate (Supplementary Material Figs S5 and S6; see above). This may support a scenario, under which epitheca formation is ancestral in Azadinium and derived in Amphidoma (Fig. 20). However, monophyly of the former including A. concinnum should be treated with caution the molecular trees given.

The position of the ventral pore either on the left or on the right lateral side of the dinophyte cell appears not only as a diagnostic, but also phylogenetically informative trait. With the exception of $A$. polongum, the species with a ventral pore on the left lateral side constitute a monophyletic group, while the members with a ventral pore on the right lateral side are paraphyletic. This makes an evolutionary displacement of the ventral pore from the 
1 right to the left lateral side plausible as inferred from the molecular phylogenetic trees.

2 However, the ventral pore located on the left lateral side in A. polongum must then be

3 interpreted as result of an independent development. The distribution of an antapical spine

4 does likewise not match entirely with the molecular phylogenetic trees. The first four

5 branching lineages consistently include species with such a structure, providing evidence that

6 a spine belongs to the 'bauplan' of the Amphidomataceae. However, the members lacking a

7 spine do again not constitute a monophyletic group, and its loss must be considered as result

8 of independent evolutionary events. Presence / absence of a spine may vary even within

9 species (i.e., A. dalianense), indicating the evolutionary plasticity of this trait.

11 Distribution and Toxins

Azadinium has been described from the North Sea, although knowledge on the biogeography currently is rather limited and patchy. However, there is growing evidence that Azadinium probably has a world-wide distribution: It has been recorded from the warm Pacific Ocean off

15 Mexico (Hernández-Becerril et al. 2012), to form blooms along the Argentinean South

16 Atlantic shelf (Akselman and Negri 2012), to occur along the Asian Pacific coast (Gu et al.

17 2013b; Potvin et al. 2012), is now known from the Mediterranean (Percopo et al. 2013), has

18 been included in the check list of Black Sea phytoplankton

19 (http://phyto.bss.ibss.org.ua/wiki/Azadinium spinosum), and is verified in SEM plankton 20 samples from the open Indian Ocean (Consuelo Carbonell-Moore, Oregon State Univ., USA, 21 pers. commun.). Here, we now report on a range extension of Azadinium to a sub-polar area 22 (Irminger Sea, northern Atlantic Ocean off Island). This comes not too much as a surprise 23 given the recent record of $A$. spinosum and A. polongum from the Shetland Islands (Tillmann 24 et al. 2012b), which are located in the northernmost part of the North Sea and are largely 25 influenced by the North Atlantic Ocean. In addition, G. parva (which almost certainly is a 26 species of Azadinium, see above) has been recorded from the central Norwegian Sea towards 
1 Iceland (Ramsfjell 1959), whereas “G. gracilis” which probably also refers to a species of

2 Azadinium, originates from the Canadian Arctic (Bérard-Therriault et al. 1999; Holmes 1956).

3 We do not yet have quantitative data of Azadinium species from the Irminger Sea and Island,

4 but onboard LM of concentrated bottle samples indicate a generally low abundance of

5 Azadinium-like cells. More detailed studies on the seasonal variation, also using molecular

6 probes (Toebe et al. 2013), are needed to provide data on the quantitative importance of these

7 species in cold water ecosystems. With now three new species and the additional record of $A$.

8 languida and A. dexteroporum (unpubl. observ.), the diversity of the Amphidomataceae in

9 that region seems to be high, especially since our presented findings are based on a single cruise and a limited number of stations.

We failed to detect known azaspiracids and other compounds producing AZA-

12 characteristic MS fragments in all available strains of the three new species. What we know

13 from work with A. spinosum is that AZA production in a given strain is constitutive, that

14 toxins are found in significant amounts in the cells at all stages of growth and at all

15 environmental conditions tested so far (Jauffrais et al. 2013). However, we must be aware that

16 toxin production can be variable among strains of a single species. Azadinium poporum was

17 reported to be a non-toxigenic species at first (Tillmann et al. 2011) but later, it was proved to

18 produce several different novel AZAs, although with a high strain variability (Gu et al. 2013b;

19 Krock et al. 2012). Moreover, some new Asian strains produce the previously known toxic

20 AZA-2, and - among a total of 22 strains of A. poporum analysed so far - four strains without

21 any detectable AZAs are found (Gu et al. 2013b; Krock et al. in press). Only a single strain of

22 A. cuneatum and A. concinnum and three strains of $A$. trinitatum are available and have been

23 examined so far, and clearly more strains are needed to evaluate if absence of AZAs is a

24 consistent and species-specific trait of these new Azadinium species. 


\section{Methods}

2

3 Isolation and culture: A number of strains of Azadinium (i.e., strains A2D11, 4A8, 4B11,

4 3D6, 1C6) were established from water samples collected at two stations between Greenland

5 and Island (station 525: $62^{\circ} 13.95^{\prime} \mathrm{N}, 37^{\circ} 27.31^{\prime} \mathrm{W}$; station 526: $64^{\circ} 45.71^{\prime} \mathrm{N}, 2^{\circ} 56.74^{\prime} \mathrm{W}$ )

6 and three stations off the north-western coast of Island (station 532: $65^{\circ} 27.00^{\prime} \mathrm{N}, 24^{\circ} 39.00^{\prime} \mathrm{W}$;

7 station 537 : $65^{\circ} 10.00^{\prime} \mathrm{N}, 2^{\circ} 26.97^{\prime} \mathrm{W}$; station 540 : $64^{\circ} 43.00^{\prime} \mathrm{N}, 24^{\circ} 01.50^{\prime} \mathrm{W}$ ) during a cruise

8 aboard the research vessel “Maria S. Merian” in August 2012 (Fig. 1, Table 1). One-Liter

9 Niskin bottle samples (10 m depth) from each station was pre-screened (20 $\mu \mathrm{m}$ Nitex gauze), gently concentrated by gravity filtration using a 3- $\mu$ m polycarbonate filter, and examined

11 using an inverted microscope (Axiovert 200M, Zeiss, Germany). Cells of Azadinium (generally rare in the samples) were visually pre-identified at high magnification (640X) based on general cell size and shape, on the presence of a theca and presence of a distinct and pointed apex.

15 Pre-identified cells were isolated by micro-capillary into wells of 96-well plates filled with $0.2 \mathrm{~mL}$ filtered seawater. By this transfer technique, the inclusion of non-target cells is unavoidable. Therefore, each primary well of isolation was partitioned as $10 \mu \mathrm{L}$ quantities distributed into 20 new wells pre-filled with $0.2 \mathrm{~mL}$ filtered seawater. Plates were incubated at $10{ }^{\circ} \mathrm{C}$ under a photon flux density of appr. $50 \mu \mathrm{mol} \mathrm{m} \mathrm{m}^{-2} \mathrm{~s}^{-1}$ on a $16: 8 \mathrm{~h}$ light:dark photocycle in a controlled environment growth chamber (Model MIR 252, Sanyo Biomedical,

21 Wood Dale, USA). After 4 weeks of growth, plates were inspected for the presence of

22 Azadinium-like cells as inferred from the typical size, shape, and swimming behavior of other known Azadinium species. From each positively identified well, a clonal strain was established by isolation of single cells by micro-capillary. Established cultures were routinely held at both $10{ }^{\circ} \mathrm{C}$ and $15{ }^{\circ} \mathrm{C}$ in an natural seawater medium prepared with sterile-filtered $(0.2$ $\mu \mathrm{m}$ VacuCap filters, Pall Life Sciences, Dreieich, Germany) Antarctic seawater (salinity: 34 
1 psu, pH adjusted to 8.0) and enriched with 1/10 strength K-medium (Keller et al. 1987);

2 slightly modified by omitting addition of ammonium ions). All strains are available on

3 request.

4

For toxin analysis, strains were grown in $250 \mathrm{ml}$ plastic culture flasks at $15^{\circ} \mathrm{C}$ under a photon flux density of $50 \mu \mathrm{mol} \mathrm{m} \mathrm{m}^{-2} \mathrm{~s}^{-1}$ on a 16:8 h light:dark photocycle. For each harvest, cell density was determined by settling lugol fixed samples and counting $>800$ cells under an inverted microscope. Densely grown strains (ranging from 3-11 x $10^{4}$ cells $\mathrm{mL}^{-1}$ ) were harvested in 4 x 50 mL centrifugation tubes by centrifugation (Eppendorf 5810R, Hamburg, Germany) at $3220 \mathrm{~g}$ for $10 \mathrm{~min}$. Each four pellets from a single strain were combined in an microtube, again centrifuged (Eppendorf 5415, 16,000 $\mathrm{g}, 5 \mathrm{~min})$, and stored frozen $\left(-20^{\circ} \mathrm{C}\right)$ until use. Growth and harvest procedures were repeated several times to yield a total number of at least $2 \times 10^{8}$ cells. Total volume and number of cells harvested for the different strains was: 4A8: 3.3 L, $2.1 \times 10^{8}$ cells; 4B11: 4.1 L, 2.6 × $10^{8}$ cells; A2D11: 2.5 L, 2.0 x $10^{8}$ cells; 3D6: 4.7 L, 3.6 x $10^{8}$ cells; 1C6: 8.6 L, $4.6 \times 10^{8}$ cells.

All harvests of the different strains were combined in two mL methanol and homogenized with a sonotrode (Sonoplus HD 2070, Bandelin, Berlin, Germany) in 70 cycles at 100\% power for 70 s. Homogenates were centrifuged (Eppendorf 5810 R, Hamburg, Germany) at $15^{\circ} \mathrm{C}$ and $3220 \mathrm{x} \mathrm{g}$ for $15 \mathrm{~min}$. Supernatants were collected, and pellets twice re-extracted with one mL methanol each. Combined extracted were reduced in a rotary evaporator (Büchi, Konstanz, Germany) at reduced pressure and $40{ }^{\circ} \mathrm{C}$ water bath temperature to a volume $<0.5$ $\mathrm{mL}$ and were then taken up in acetone to a final volume of $1 \mathrm{~mL}$. The extracts were transferred to a $0.45 \mu \mathrm{m}$ pore-size spin-filter (Millipore Ultrafree, Eschborn, Germany) and centrifuged (Eppendorf $5415 \mathrm{R}$, Hamburg, Germany) at $800 \mathrm{x} g$ for $30 \mathrm{~s}$, with the resulting filtrate transferred into a liquid chromatography (LC) autosampler vial for LC-MS/MS analysis. 
Light microscopy (LM): Observation of live or fixed cells was carried out with a

2 stereomicroscope (Olympus SZH-ILLD) and an inverted microscope (Axiovert 200 M, Zeiss,

3 Germany) as well, equipped with epifluorescence and differential interference contrast optics.

4 Light microscopic examination of the thecal plate tabulation was performed on formalin fixed

5 cells (1\% final concentration) stained with calcofluor white (Fritz and Triemer 1985). Shape

6 and position of the nucleus was determined after staining of formalin fixed cells with 4'-6-

7 diamidino-2-phenylindole (DAPI, $0.1 \mu \mathrm{g} \mathrm{mL}^{-1}$ final concentration) for $10 \mathrm{~min}$. Photographs

8 were taken with a digital camera (Axiocam MRc5, Zeiss, Germany).

$9 \quad$ Cell length and width were measured at $1000 \mathrm{x}$ microscopic magnification using Zeiss

Axiovision software (Zeiss, Germany) and freshly fixed cells (formalin, final concentration $1 \%)$ of strains growing at $15^{\circ} \mathrm{C}$.

Scanning electron microscopy (SEM): For SEM examination of thecal plates, cells

from growing strains held at $15^{\circ} \mathrm{C}$ were fixed, prepared, and collected on 3 - $\mu$ m polycarbonate filters (Millipore) as described by Tillmann et al. (2011). Filters were mounted on stubs, sputter-coated (Emscope SC500, Ashford, UK) with gold-palladium, and viewed under a scanning electron microscope (FEI Quanta FEG 200, Eindhoven, Netherlands). Some SEM micrographs were presented on a black background using Adobe Photoshop 6.0 (Adobe pores. preserved at the same point in time and was deposited at the Senckenberg Research Institute and Natural History Museum, Centre of Excellence for Dinophyte Taxonomy (CEDiT), Germany.

Chemical analysis for azaspiracids and precursor ion experiments: For all strains, a deep analysis for the presence of AZAs was conducted. Samples were analyzed by LC coupled to tandem mass spectrometry (LC-MS/MS) according to the methods described in 
1 detail by Tillmann et al. (2009). Selected reaction monitoring (SRM) experiments were

2 carried out in positive ion mode by selecting the following transitions given in Table 2.

3 Precursors of the fragments $\mathrm{m} / \mathrm{z} 348$ and $\mathrm{m} / \mathrm{z} 362$ were scanned in the positive ion

4 mode from $\mathrm{m} / \mathrm{z} 400$ to 950 under the following conditions: curtain gas: 10 psi, CAD: medium,

5 ion spray voltage: $5500 \mathrm{~V}$, temperature: ambient, nebulizer gas: 10 psi, auxiliary gas: off,

6 interface heater: on, declustering potential: $100 \mathrm{~V}$, entrance potential: $10 \mathrm{~V}$, collision energy:

$7 \quad 70 \mathrm{~V}$, exit potential: $12 \mathrm{~V}$.

8 Molecular phylogenetic analysis: Two optional methods were used to obtain

9 genomic DNA: 1) DNA extraction from an exponentially growing strain of Azadinium prior

to DNA amplification or 2) direct PCR amplification from a single cell isolated from

particular strains. For the first approach, cells from approximately $20 \mathrm{~mL}$ of each strain were harvested by centrifugation (4000 rpm, $20 \mathrm{~min}$ ). The genomic DNA was extracted using the CTAB ( $N$-cetyl- $N, N, N$-trimethylammoniumbromide) method (Doyle and Doyle 1987). For the second approach, each cell was deposited on a glass slide, using a micropipette under the 15 Olympus IMT2 inverted light microscope. Subsequently, each cell was placed in a drop of a sodium thiosulfate solution to decrease the inhibiting effect of the fixative on the PCR

17 (Auinger et al. 2008), rinsed twice in double distilled water $\left(\mathrm{ddH}_{2} \mathrm{O}\right)$ before transfer to a 0.2mL PCR tube containing $3 \mu \mathrm{L}$ of $\mathrm{ddH}_{2} \mathrm{O}$, and stored at $-20^{\circ} \mathrm{C}$ until direct PCR. The small sbunit (SSU), the internal transcribed spacers (ITS) including the 5.8S, and the large subunit (LSU, D1+D2 region) of the rRNA operon, were amplified using the primers specified in Nézan et al. (2012). Genomic DNA was amplified in $25 \mu \mathrm{L}$ PCR reaction containing either $1 \mu \mathrm{L}$ of extracted DNA or isolated cells, $6.5 \mu \mathrm{L}$ of ultrapure water, $2.5 \mu \mathrm{L}$ of each primer $(10 \mu \mathrm{M})$, and $12.5 \mu \mathrm{L}$ of PCR Master Mix 1X (Promega, Madison, WI, USA), which included Taq polymerase, dNTPs, $\mathrm{MgCl}_{2}$, and reaction buffer. PCRs were performed in a Mastercycler Personal (Eppendorf, Hamburg, Germany) as follows: one initial denaturation step at $94{ }^{\circ} \mathrm{C}$ for 2 min, followed by 45 cycles each consisting of $94{ }^{\circ} \mathrm{C}$ for 30 s, $52{ }^{\circ} \mathrm{C}$ for 1 
$1 \mathrm{~min}$, and $72{ }^{\circ} \mathrm{C}$ for $4 \mathrm{~min}$, and a final elongation at $72{ }^{\circ} \mathrm{C}$ for $5 \mathrm{~min}$. To obtain at least two

2 sequences of each locus and each strain, cloning was performed if applicable. Then, PCR

3 products were cloned in the pGEM ${ }^{\circledR}$-T Easy Vector System I (Promega, Madison, WI, USA),

4 visualized, purified, and sequenced following standard protocols (Nézan et al. 2012). At least

5 three positive clones were sequenced in both directions.

In total, 45 new sequences were generated in the course of the present study (Table 1).

7 The taxon sample covered the known molecular and morphological diversity of the

8 Amphidomataceae (43 operational taxonomic units: OTUs corresponding to eleven species

9 currently recognized), including 15 OTUs of the three new species. All members of the

Gymnodiniaceae, Kareniaceae, Peridiniaceae, and Thoracosphaeraceae exhibiting complete

SSU+ITS+LSU sequences (with branches of comparable length in molecular trees: Gu et al. 2013a) were used as outgroup (Tab. S1). The data set was partitioned into four parts (i.e., SSU, ITS, LSU $\leq \mathrm{D} 2$, LSU $\geq \mathrm{D} 3$ ), and the nucleotide sequences were separately aligned using MAFFT v6.624b (Katoh et al., 2005; freely available at http://align.bmr.kyushuu. ac.jp/mafft/software/) with the --auto option and considering the secondary structure of the molecules (i.e., the 'QINSI’ option). The sequences were concatenated afterwards, and the final data matrix is available as NEXUS file upon request. available from the CIPRES Science Gateway (Miller et al., 2010) with maximum likelihood (ML) and Bayesian inference methods. For ML calculations, RAxML v7.2.6 (Stamatakis 2006; freely available at http://wwwkramer.in.tum.de/exelixis/software.html) was applied. To determine best fitted ML-trees, we executed 10-tree searches from distinct random stepwise addition sequence maximum parsimony starting trees and 1,000 non-parametric bootstrap replicates. Bayesian analyses was performed using MrBayes v3.1.2 (Ronquist and Huelsenbeck, 2003; freely available at http://mrbayes.csit.fsu.edu/download.php), under the 
1 RAxML. We ran two independent analyses of four chains (one cold and three heated) under

2 the partition data mode with 15,000,000 cycles, sampled every 1,000th cycle, with an

3 appropriate burn-in (10\%) as inferred from the evaluation of the trace files using Tracer v1.5

4 (http://tree.bio.ed.ac.uk/software/tracer/). Statistical support values (LBS: ML bootstrap

5 support, BPP: Bayesian posterior probabilities) were drawn on the resulting, best-scoring ML 6 tree.

7

8

\section{Acknowledgements}

10

11 Thanks to Captain Bergmann and the FS Maria S. Merian crew for their assistance and

12 support for the collection of field material. Financial support was provided by the PACES

13 research program of the Alfred Wegener Institute as part of the Helmholtz Foundation

14 initiative in Earth and Environment. This work is part of the project " Azaspiracids:

15 Toxicological Evaluation, Test Methods and Identification of the Source Organism”

16 [PBA/AF/08/001(01)], which is carried out under the Sea Change strategy with the support of

17 the Marine Institute and the Marine Research Sub-Programme of the National Development

18 Plan 2007-2013, co-financed under the European Regional Development Fund. We are

19 grateful to Karine Chèze (MNHN, Concarneau) for her contribution to sequencing. 
1 Table 1. Overview of Azadinium strains analyzed in the present study

\begin{tabular}{|c|c|c|c|c|c|c|}
\hline strain & species & $\begin{array}{l}\text { isolated } \\
\text { from } \\
\text { station } \mathrm{nr} .\end{array}$ & $\begin{array}{c}\text { AZA } \\
\text { toxins }\end{array}$ & $\begin{array}{l}\text { Fragment } \\
\text { Sequence }\end{array}$ & $\begin{array}{l}\text { Molecular } \\
\text { Method }\end{array}$ & Accession nr. \\
\hline A2D11 & $\begin{array}{c}\text { Azadinium } \\
\text { trinitatum }\end{array}$ & 540 & negative & $\begin{array}{c}\text { ITS-LSU(D1-D3) } \\
\text { ITS } \\
\text { LSU (D1-D3) } \\
\text { LSU (D1-D3) } \\
\text { LSU (D1-D3) } \\
\text { SSU } \\
\text { SSU }\end{array}$ & $\begin{array}{l}\text { DNA extract } \\
\text { DNA extract } \\
\text { cloning (clone2) } \\
\text { cloning (clone5) } \\
\text { cloning (clone9) } \\
\text { DNA extract } \\
\text { DNA extract }\end{array}$ & $\begin{array}{l}\text { KJ481804 } \\
\text { KJ481806 } \\
\text { KJ481814 } \\
\text { KJ481805 } \\
\text { KJ481807 } \\
\text { KJ481813 } \\
\text { KJ481803 }\end{array}$ \\
\hline $4 \mathrm{~A} 8$ & $\begin{array}{c}\text { Azadinium } \\
\text { trinitatum }\end{array}$ & 537 & negative & $\begin{array}{c}\text { ITS-LSU(D1-D3) } \\
\text { ITS } \\
\text { LSU (D1-D3) } \\
\text { SSU } \\
\text { SSU }\end{array}$ & $\begin{array}{l}\text { DNA extract } \\
\text { DNA extract } \\
\text { DNA extract } \\
\text { DNA extract } \\
\text { DNA extract } \\
\end{array}$ & $\begin{array}{l}\text { KJ481812 } \\
\text { KJ481809 } \\
\text { KJ481810 } \\
\text { KJ481808 } \\
\text { KJ481811 } \\
\end{array}$ \\
\hline 4B11 & $\begin{array}{c}\text { Azadinium } \\
\text { trinitatum }\end{array}$ & 537 & negative & $\begin{array}{c}\text { ITS-LSU(D1-D3) } \\
\text { ITS-LSU(D1-D3) } \\
\text { SSU } \\
\text { SSU }\end{array}$ & $\begin{array}{l}\text { DNA extract } \\
\text { DNA extract } \\
\text { DNA extract } \\
\text { DNA extract }\end{array}$ & $\begin{array}{l}\text { KJ481816 } \\
\text { KJ481818 } \\
\text { KJ481815 } \\
\text { KJ481817 }\end{array}$ \\
\hline 3D6 & $\begin{array}{l}\text { Azadinium } \\
\text { cuneatum }\end{array}$ & 532 & negative & $\begin{array}{c}\text { ITS-LSU(D1-D3) } \\
\text { ITS-LSU(D1-D3) } \\
\text { LSU (D1-D3) } \\
\text { LSU (D1-D3) } \\
\text { LSU (D1-D3) } \\
\text { SSU } \\
\text { SSU }\end{array}$ & $\begin{array}{l}\text { DNA extract } \\
\text { DNA extract } \\
\text { cloning (clone 1) } \\
\text { cloning (clone 6) } \\
\text { cloning (clone 10) } \\
\text { DNA extract } \\
\text { DNA extract }\end{array}$ & $\begin{array}{l}\text { KJ481820 } \\
\text { KJ481823 } \\
\text { KJ481824 } \\
\text { KJ481825 } \\
\text { KJ481821 } \\
\text { KJ481819 } \\
\text { KJ481822 }\end{array}$ \\
\hline 1C6 & $\begin{array}{l}\text { Azadinium } \\
\text { concinnum }\end{array}$ & & negative & $\begin{array}{c}\text { ITS-LSU(D1-D3) } \\
\text { ITS } \\
\text { LSU (D1-D3) } \\
\text { LSU (D1-D3) } \\
\text { LSU (D1-D3) } \\
\text { SSU } \\
\text { SSU }\end{array}$ & $\begin{array}{c}\text { Single cell } \\
\text { DNA extract } \\
\text { cloning (clone 4) } \\
\text { cloning (clone 5) } \\
\text { cloning (clone 6) } \\
\text { Single cell } \\
\text { Single cell }\end{array}$ & $\begin{array}{l}\text { KJ481830 } \\
\text { KJ481827 } \\
\text { KJ481831 } \\
\text { KJ481832 } \\
\text { KJ481833 } \\
\text { KJ481826 } \\
\text { KJ481829 }\end{array}$ \\
\hline
\end{tabular}

2 
1 Table 2. Mass transitions $\mathrm{m} / \mathrm{z}(\mathrm{Q} 1>\mathrm{Q} 3$ mass) and their respective AZAs

\begin{tabular}{|c|c|c|}
\hline Mass transition & $\overline{A Z A}$ & Collision energy (CE) [V] \\
\hline $716>698$ & AZA-33 & 40 \\
\hline $816>798$ & AZA-34, AZA-39 & 40 \\
\hline $816>348$ & AZA-39 & 70 \\
\hline $828>810$ & AZA-3 & 40 \\
\hline $828>658$ & AZA-3 & 70 \\
\hline $830>812$ & AZA-35, AZA-38 & 40 \\
\hline $830>348$ & AZA-38 & 70 \\
\hline $842>824$ & AZA-1, AZA-6, AZA-40 & 40 \\
\hline $842>672$ & AZA-1 & 70 \\
\hline $842>348$ & AZA-40 & 70 \\
\hline $844>826$ & AZA-4, AZA-5 & 40 \\
\hline $846>828$ & AZA-37 & 40 \\
\hline $846>348$ & AZA-37 & 70 \\
\hline $854>846$ & AZA-41 & 40 \\
\hline $854>670$ & AZA-41 & 70 \\
\hline $856>838$ & AZA-2 & 40 \\
\hline $856>672$ & AZA-2 & 70 \\
\hline $858>840$ & $\begin{array}{l}\text { AZA-7, AZA-8, AZA-9, } \\
\text { AZA-10, AZA-36 }\end{array}$ & 40 \\
\hline $858>348$ & AZA-36 & 70 \\
\hline $860>842$ & Undescribed & 40 \\
\hline $872>854$ & AZA-11, AZA-12 & 40 \\
\hline
\end{tabular}


Table 3. Compilation of morphological features of all species of Azadinium and of the related species Amphidoma languida

\begin{tabular}{|c|c|c|c|c|c|c|c|c|c|c|c|c|}
\hline & A. spinosum & A. obesum & A. poporum & $\begin{array}{c}\text { A. caudatum } \\
\text { var. margalefii }\end{array}$ & $\begin{array}{l}\text { A. caudatum } \\
\text { var. caudatum }\end{array}$ & $\begin{array}{c}\text { A. } \\
\text { polongum }\end{array}$ & $\begin{array}{c}\text { A. } \\
\text { dexteroporum }\end{array}$ & $\begin{array}{c}\text { A. } \\
\text { dalianense }\end{array}$ & A. trinitatum & A. cuneatum & $\begin{array}{c}\text { A. } \\
\text { concinnum }\end{array}$ & $\begin{array}{c}\text { Amphidoma } \\
\text { languida }\end{array}$ \\
\hline $\begin{array}{c}\text { Length range } \\
\text { (mean) }\end{array}$ & $\begin{array}{c}12.3-15.7 \\
(13.8) \\
\end{array}$ & $\begin{array}{c}13.3-17.7 \\
(15.3) \\
\end{array}$ & $\begin{array}{c}11.3-16.3 \\
(13.0) \\
\end{array}$ & $25.0-42.1$ & $35.5-52.5$ & $\begin{array}{c}10.1-17.4 \\
(13.0)\end{array}$ & $\begin{array}{c}7.0-10.0 \\
(8.5) \\
\end{array}$ & $\begin{array}{c}11.9-18.0 \\
(13.9)\end{array}$ & $\begin{array}{c}11.5-16.7 \\
(14.1) \\
\end{array}$ & $\begin{array}{c}11.2-16.9 \\
(14.2) \\
\end{array}$ & $\begin{array}{c}8.0-11.5 \\
(9.5) \\
\end{array}$ & $\begin{array}{c}12.9-15.5 \\
(13.9) \\
\end{array}$ \\
\hline $\begin{array}{c}\text { Width range } \\
\text { (mean) }\end{array}$ & $\begin{array}{c}7.4-10.3 \\
(8.8) \\
\end{array}$ & $\begin{array}{c}10.0-14.3 \\
(11.7) \\
\end{array}$ & $\begin{array}{c}8.0-11.6 \\
(9.8) \\
\end{array}$ & $18.4-30.0$ & $25.0-36.7$ & $\begin{array}{c}\text { 7.4-13.6 } \\
(9.7) \\
\end{array}$ & $\begin{array}{c}5.0-8.0 \\
(6.2) \\
\end{array}$ & $\begin{array}{c}8.3-12.7 \\
(10.1) \\
\end{array}$ & $\begin{array}{c}7.3-11.5 \\
(9.2) \\
\end{array}$ & $\begin{array}{c}8.3-12.7 \\
(10.8) \\
\end{array}$ & $\begin{array}{c}5.6-8.3 \\
(6.6) \\
\end{array}$ & $\begin{array}{c}9.7-14.1 \\
(11.9) \\
\end{array}$ \\
\hline $\mathrm{L} / \mathrm{W}$ ratio & 1.6 & 1.3 & 1.3 & 1.2 & 1.2 & 1.3 & 1.4 & 1.4 & 1.5 & 1.3 & 1.4 & 1.3 \\
\hline $\begin{array}{l}\text { Number apical / } \\
\text { intercalary plates }\end{array}$ & $4 / 3$ & $4 / 3$ & $4 / 3$ & $4 / 3$ & $4 / 3$ & $4 / 3$ & $4 / 3$ & $3 / 2$ & $4 / 3$ & $4 / 3$ & $4 / 3$ & $6 / 0$ \\
\hline Antapical spine & spine & No & no & $\begin{array}{l}\text { short horn, } \\
\text { long spine }\end{array}$ & $\begin{array}{l}\text { long horn, } \\
\text { short spine }\end{array}$ & spine & spine & $\begin{array}{l}\text { rare, short } \\
\text { spine }\end{array}$ & $\begin{array}{c}\text { spine, } \\
\text { (unstable?) }\end{array}$ & no & spine & no \\
\hline Stalked pyrenoid & 1 & none & up to four & none & not shown & none & 1 & up to two & 1 (up to two) & 1 (up to two) & none & 1 \\
\hline $1{ }^{\prime \prime}$ adjacent to $1 \mathrm{a}$ & yes & no & yes & yes & yes & yes & yes & yes & yes & no & no & not applicable \\
\hline Vp position & left side of $1^{\prime}$ & $\begin{array}{c}\text { left side of } \\
1^{\prime}\end{array}$ & $\begin{array}{l}\text { pore plate, } \\
\text { left side }\end{array}$ & $\begin{array}{l}\text { pore plate, } \\
\text { right side }\end{array}$ & right side of $1^{\prime}$ & $\begin{array}{c}\text { left side of } \\
1^{\prime}\end{array}$ & $\begin{array}{l}\text { end of pore } \\
\text { plate, right } \\
\text { side }\end{array}$ & $\begin{array}{l}\text { pore plate, } \\
\text { left side }\end{array}$ & $\begin{array}{l}\text { end of pore } \\
\text { plate, left side }\end{array}$ & $\begin{array}{l}\text { middle of pore } \\
\text { plate, left side }\end{array}$ & $\begin{array}{l}\text { pore plate, } \\
\text { right side }\end{array}$ & $\begin{array}{c}\text { right side of } \\
1^{\prime} \text { (anterior } \\
\text { position) }\end{array}$ \\
\hline $\begin{array}{l}\text { Pore plate } \\
\text { symmetry }\end{array}$ & $\begin{array}{l}\text { suture to } \\
\text { 1'slightly } \\
\text { asymmetric, } \\
\text { right side } \\
\text { more apical }\end{array}$ & $\begin{array}{l}\text { suture to } \\
\text { 1'slightly } \\
\text { asymmetric, } \\
\text { right side } \\
\text { more apical }\end{array}$ & $\begin{array}{c}\text { suture to } 1^{\prime} \\
\text { slightly } \\
\text { asymmetric., } \\
\text { left side } \\
\text { more apical }\end{array}$ & $\begin{array}{l}\text { suture to } \\
1^{\prime} \text { almost } \\
\text { symmetric }\end{array}$ & $\begin{array}{l}\text { suture to } \\
1^{\prime} \text { almost } \\
\text { symmetric }\end{array}$ & $\begin{array}{c}\text { Po } \\
\text { elongated, } \\
\text { suture to } \\
\text { 1'almost } \\
\text { symmetric }\end{array}$ & $\begin{array}{l}\text { suture to } 1^{\prime} \\
\text { strongly } \\
\text { asymmetric, } \\
\text { left side more } \\
\text { apical } \\
\end{array}$ & $\begin{array}{l}\text { suture to } \\
1^{\prime} \text { almost } \\
\text { symmetric }\end{array}$ & $\begin{array}{l}\text { suture to } 1^{\prime} \\
\text { asymmetric, } \\
\text { right side } \\
\text { more apical }\end{array}$ & $\begin{array}{c}\text { suture to } \\
1 \text { 'strongly } \\
\text { asymmetric, left } \\
\text { side more apical }\end{array}$ & $\begin{array}{l}\text { suture to } \\
1^{\prime} \text { almost } \\
\text { symmetric }\end{array}$ & $\begin{array}{c}\text { suture to } \\
1^{\prime} \text { almost } \\
\text { symmetric }\end{array}$ \\
\hline Shape of 1'plate & $\begin{array}{c}\text { wide } \\
\text { posteriorly }\end{array}$ & $\begin{array}{c}\text { narrow } \\
\text { posteriorly }\end{array}$ & $\begin{array}{c}\text { wide } \\
\text { posteriorly }\end{array}$ & $\begin{array}{c}\text { narrow } \\
\text { posteriorly }\end{array}$ & $\begin{array}{c}\text { narrow } \\
\text { posteriorly }\end{array}$ & $\begin{array}{l}\text { wide post., } \\
\text { narrowed } \\
\text { anteriorly } \\
\end{array}$ & $\begin{array}{c}\text { narrow } \\
\text { posteriorly }\end{array}$ & $\begin{array}{c}\text { wide } \\
\text { posteriorly }\end{array}$ & $\begin{array}{c}\text { narrow } \\
\text { posteriorly }\end{array}$ & $\begin{array}{l}\text { wide posteriorly, } \\
\text { anteriorly copped }\end{array}$ & $\begin{array}{c}\text { narrow } \\
\text { posteriorly }\end{array}$ & $\begin{array}{c}\text { narrow } \\
\text { posteriorly }\end{array}$ \\
\hline $\begin{array}{l}\text { Rel. size first and } \\
\text { last intercalary }\end{array}$ & large & small & large & small & small & small & small & large & large & large & small & not applicable \\
\hline $\begin{array}{l}\text { Relative size } \\
\text { apical plates }\end{array}$ & medium & medium & medium & medium & medium & medium & small & medium & small & large & small & small \\
\hline AZAs & $\begin{array}{l}\text { AZA-1, -2, - } \\
\quad 716\end{array}$ & none & $\begin{array}{l}\text { Aza-2, -846, } \\
\text {-872, none } \\
\text { (strain } \\
\text { specific) }\end{array}$ & none & not tested & none & $\begin{array}{l}\text { Aza-3, -7; } \\
\text { none } \\
\text { (strain } \\
\text { specific) }\end{array}$ & none & none & none & none & $\begin{array}{l}\text { AZA-816, - } \\
\quad 830\end{array}$ \\
\hline Records & $\begin{array}{l}\text { North Sea, } \\
\text { Atlantic, } \\
\text { Pacific off } \\
\text { Mexico }\end{array}$ & North Sea & $\begin{array}{l}\text { North Sea, } \\
\text { Asia Pacific }\end{array}$ & $\begin{array}{l}\text { Mediterranean, } \\
\text { North Sea, } \\
\text { Atlantic }\end{array}$ & $\begin{array}{l}\text { Mediterranean, } \\
\text { North Sea, } \\
\text { Atlantic }\end{array}$ & North Sea & $\begin{array}{l}\text { Mediterranean, } \\
\text { North Atlantic }\end{array}$ & Asian Pacific & $\begin{array}{l}\text { North } \\
\text { Atlantic }\end{array}$ & North Atlantic & $\begin{array}{l}\text { North } \\
\text { Atlantic }\end{array}$ & $\begin{array}{l}\text { North } \\
\text { Atlantic }\end{array}$ \\
\hline
\end{tabular}

3 References : ${ }^{\text {a) }}$ Tillmann et al. $2009 ;{ }^{\text {b) }}$ Salas et al. $2012 ;{ }^{\text {c) }}$ Tillmann et al. 2012b ; ${ }^{\text {d) }}$ Tillmann et al $2010 ;{ }^{\text {e) }}$ Tillmann et al. $2011 ;{ }^{\text {f) }}$ Potvin et al. $2012 ;{ }^{\text {g) }}$ Gu et al. $42013 ;{ }^{\text {h) }}$ Krock et al. $2012 ; ;^{\text {i) }}$ Nézan et al. $2012 ;{ }^{\text {j) }}$ Tillmann et al. $2014 \mathrm{~b} ;{ }^{k}$ Tillmann et al. 2012b ; ${ }^{\text {l) }}$ Percopo et al. 2013 ; ${ }^{\text {m) }}$ Tillmann et al. (unpublished); ${ }^{\text {n) }}$ Luo 5 et al. 2013; ${ }^{\circ)}$ This study; ${ }^{\text {p) }}$ Tillmann et al. 2012a 
1 Figure legends

2 Figure 1. Geographical locations of selected sampling stations of the "Maria S. Merian”

3

4 expedition 2012.

Figzre 2. Azadinium trinitatum (strain 4A8). Light microscopy of formalin fixed cells except for E (Lugol fixed). (A-C) General size and shape. Note the presence of a large pyrenoid in the epicone and the presence of an antapical spine (arrow in B and C). (D) Lateral view to illustrate a ribbon-like connection of the parietally located chloroplast from epi- to the hypocone. (E) Cell with a purple stained pyrenoid and additional large grains of presumably storage material. (F-G) Variations in pyrenoid, a cell with a large and unusually shaped pyrenoid (F) and a cell with two pyrenoids (G). (H-K) Formalin fixed cell stained with DAPI as viewed using UV excitation showing nucleus and chloroplast shape and position. (L) A cell with UV excitation after calcofluor staining showing a dorsal view of the thecal plates. Scale bars $=2 \mu \mathrm{m}$.

Figure 3. Azadinium trinitatum: SEM micrographs of different thecate cells (A: strain 4B11; all others: strain A2D11). (A-C) Ventral view. (D) Dorsal view. Scale bars $=2 \mu \mathrm{m}$.

Figure 4. Azadinium trinitatum. Diagrammatic illustration of thecal plates (as inferred from the investigation of strain A2D11). (A) ventral view. (B) Dorsal view. (C) Apical view. (D) Antapical view. Abbreviations: $\mathrm{Sa}, \mathrm{Sd}, \mathrm{Sm}, \mathrm{Sp}, \mathrm{Ss}$ : sulcal plates as detailed in Figure 5. Arrows in C-D indicate plate overlap pattern.

Figure 5. Azadinium trinitatum: SEM micrographs of different cells (A, D, F, H: strain 4B11; B, G: strain 4A8; C, E, I: strain A2D11). (A, B) Apical view showing the complete series of epithecal plates. Black arrows in (B) exemplarily indicate postion of 
differently sized pores on the thecal plates. (C-F) Epitheca in ventral (C), dorsal (D), left lateral (E) or right lateral (F) view. (G-I) Details of the apical pore complex (APC). (G, H) APC in apical view. (I) APC viewed interiorly of the cell. Po = pore plate, $\mathrm{vp}=$ ventral pore (arrow); $\mathrm{x}=\mathrm{X}$-plate, $\mathrm{cp}=$ cover plate. Scale bars $=2 \mu \mathrm{m}(\mathrm{A}-\mathrm{F})$ or $=0.5 \mu \mathrm{m}$ (G-I).

Figure 6. Azadinium trinitatum: SEM micrographs of different cells (A, D: strain 4A8; B, C: strain 4B11; E, F: strain A2D11). (A, B) Antapical view of hypothecal plates. Black arrows exemplarily indicate postion of pores on the thecal plates. (C) Ventral view of cingulum and hypotheca. (D) Dorsal/apical view of the hypotheca showing the series of cingular plates with an interior view of the sulcal plates. (E, F) Details of the sulcal plate arrangement in external (E) and interior (F) view. Black arrows indicate the position of a row of pores on the Sa plate and of a cluster of pores on the C1 plate. (Sa: anterior sulcal plate; Sp: posterior sulcal plate; Ss: left sulcal plate; Sm: median sulcal plate; Sd: right sulcal plate). Scale bars $=2 \mu \mathrm{m}$.

Figure 7. Azadinium cuneatum (strain 3D6): LM of living (B, C) or formalin fixed (all other) cells. (A-C) General size and shape. Note the noticeable apical pore complex (arrow in B). (D) Dorsal view of the episome. Note the large pyrenoid and the parietal chloroplast. (E-F) Variation in pyrenoid, which rarely could be located in the hyposome (E), or two pyrenoids present in the episome (F). (G-H) Same cell stained with DAPI in bright $(\mathrm{G})$ or with UV excitation $(\mathrm{H})$ to indicate shape and location of the nucleus. (I-K) Different views of the same DAPI stained cell in brightfield (I), with UV excitation (J), or with blue light excitation $(\mathrm{K})$ to show shape and location of the nucleus and of the chloroplast. Scale bars $=2 \mu \mathrm{m}$. 
1 Figure 8. Azadinium cuneatum (strain 3D6): SEM micrographs of different thecate cells. (A-

2

Figure 9. Azadinium cuneatum: Diagrammatic illustration of thecal plates (as inferred from the investigation of strain 3D6). (A) ventral view. (B) Dorsal view. (C) Apical view. (D) Antapical view. Abbreviations: Sa, Sd, Sm, Sp, Ss: sulcal plates as detailed in Figure 11. Arrows in C-D indicate plate overlap pattern.

Figure 10. Azadinium cuneatum (strain 3D6): SEM micrographs of different cells to illustrate epithecal plate arrangement. (A) Apical view (B) Ventral/apical view. (C) Left lateral view (D) ventral view. (E-F) Dorsal view. Note the tetragonal shape of the median intercalary plate $2 \mathrm{a}$ in (E) and a more rarely found pentagonal configuration of plate $2 \mathrm{a}$ in $(\mathrm{F})$. Black arrows in (E) exemplarily indicate the position of pores on the precingular plates. Scale bars $=2 \mu \mathrm{m}$.

Figure 11. Azadinium cuneatum (strain 3D6): Details of the apical pore complex (APC). (AE) External view of APC in apical view. Note the rare case in (E), where the rim around Po is extending along the suture of plate 1' and 2' (arrow). (F) APC viewed interiorly from the cell. $\mathrm{Po}=$ pore plate, $\mathrm{vp}=$ ventral pore $($ arrow $) ; \mathrm{x}=\mathrm{X}$-plate, $\mathrm{cp}=$ cover plate. Scale bars $=0.5 \mu \mathrm{m}$.

Figure 12. Azadinium cuneatum (strain 3D6): SEM micrographs of different cells. (A, B) Antapical view of hypothecal plates. Black arrows in (A) exemplarily indicate the position of pores on the postcingular plates. (C) Dorsal/apical view of the hypotheca showing the series of cingular plates (C) with an interior view of the sulcal plates. (D) 
Details of the sulcal plate arrangement in external view. (E) Details of the sulcal plate arrangement in interior view. (Sa: anterior sulcal plate; Sp: posterior sulcal plate; Ss: left sulcal plate; Sm: median sulcal plate; Sd: right sulcal plate). Scale bars $=2 \mu \mathrm{m}$.

Figure 13. Azadinium concinnum (strain 1C6): LM of formalin fixed cells. (A-E) General size and shape. Note the prominent apical pore complex (black arrow in B), the very prominent antapical spine (white arrow in C), and the spherical bodies of varying size in both the epi- and hyposome (D, E). (F-I) Pair of same DAPI stained cells in either bright-field $(\mathrm{F}, \mathrm{H})$ or with UV excitation $(\mathrm{G}, \mathrm{I})$ to indicate shape and position of nucleus and chloroplast. Scale bars $=2 \mu \mathrm{m}$.

Figure 14. Azadinium concinnum (strain 1C6): SEM micrographs of different thecate cells. (A-B) Ventral view. (B) Dorsal view. Black arrows exemplarily indicate positions of pores on the thecal plates. Scale bars $=2 \mu \mathrm{m}$.

Figure 15. Azadinium concinnum: Diagrammatic illustration of thecal plates (as inferred from the investigation of strain 1C6). (A) ventral view. (B) Dorsal view. (C) Apical view. (D) Antapical view. Abbreviations: $\mathrm{Sa}, \mathrm{Sd}, \mathrm{Sm}, \mathrm{Sp}, \mathrm{Ss}$ : sulcal plates as detailed in Figure 17. Arrows in C-D indicate plate overlap pattern.

Figure 16. Azadinium concinnum (strain 1C6): SEM micrographs of different cells to illustrate epithecal plate arrangement and the apical pore complex (APC). (A) Apical view. Note a vertical row of pores on the first apical plate. (B) Ventral/apical view. (C) Left lateral view (D) Dorsal view. Black arrows indicate position of pores on the intercalary plates. (E) Right lateral view. (F-G) Ventral view of the APC. Black arrow in $(\mathrm{G})$ indicate the position of a row or pores on the first apical plate. (H) External view 
of APC in apical view. (I) APC interiorly viewed from the cell. Po = pore plate, $\mathrm{vp}=$ ventral pore (arrow); $\mathrm{x}=\mathrm{X}$-plate, $\mathrm{cp}=$ cover plate. Scale bars $=1 \mu \mathrm{m}(\mathrm{A}-\mathrm{E})$ or $=0.5$ $\mu \mathrm{m}(\mathrm{F}-\mathrm{I})$.

Figure 17. Azadinium concinnum (strain 1C6): SEM micrographs of different cells. (A) Antapical view of hypothecal plates. Note conspicuous pores near the sutures of postcingular plates (black arrows). (B-C) Ventral/antapical view of cingulum and hypotheca. (D) Detailed view of sulcal plates. (E) Dorsal/apical view of the hypotheca showing the series of cingular plates. (Sa: anterior sulcal plate; $\mathrm{Sp}$ : posterior sulcal plate; Ss: left sulcal plate; Sm: median sulcal plate; Sd: right sulcal plate). Scale bars $=1$ $\mu \mathrm{m}$.

Figure 18. Maximum likelihood tree $(-\ln =72424.15)$ of 43 OTU assigned to the Amphidomataceae, as inferred from a MAFFT generated rRNA nucleotide alignment spanning the SSU, ITS and LSU (1813 parsimony-informative positions). Major clades are indicated, and branch lengths are drawn to scale, with the scale bar indicating the number of nucleotide substitutions per site. Numbers on branches are statistical support values for the clusters to the right of them (above: ML bootstrap support values, values under 50 are not shown; below: Bayesian posterior probabilities, values under .90 are not shown), and asterisks indicate maximal support values. The tree is rooted with 88 of the Gymnodiniaceae, Kareniaceae, Peridiniaceae, and Thoracosphaeraceae.

Figure 19. Comparison of APC of A. poporum (A) and A. trinitatum (B). Scale bars $=0.5 \mu \mathrm{m}$.

Figure 20. Potential transition between apical plate pattern of Azadinium (A: interpretative for A. concinnum) and Amphidoma (B: interpretative for A. languida). When the dorsal 
apical plate $3^{\prime}$ of Azadinium is lost $(\mathbf{C})$, all three intercalary plate may get in contact to the pore plate leading to an "Amphidoma" arrangement (D). Alternatively, when the medium intercalary plate of Azadinium is lost $(\mathbf{E})$, the two remaining intercalary plates may get in contact to the pore plate leading to an "Amphidoma" configuration (F). 
References

Akselman R, Negri A (2012) Blooms of Azadinium cf. spinosum Elbrächter et Tillmann (Dinophyceae) in northern shelf waters of Argentina, Southwestern Atlantic. Harmful Algae 19:30-38

Auinger BM, Pfandl K, Boenigk J (2008) Improved methodology for identification of protists and microalgae from plankton samples preserved in Lugol's iodine solution: combining microscopic analysis with single-cell PCR. Appl Environ Microbiol 74:2505-2510

Bérard-Therriault L, Poulin M, Bossé L (1999) Guide d’identification du phytoplancton marin de l'estuaire et du golfe de Saint-Laurent incluant également certaines protozoaires. Publication spéciale canadienne des sciences halieutiques et aquatiques 128:1-387

Braña Magdalena A, Lehane M, Krys S, Fernández ML, Furey A, James KJ (2003) The first identification of azaspiracids in shellfish from France and Spain. Toxicon 42:105108

Dodge JD (1989) Some revisions of the family Gonyaulacaceae (Dinophyceae) based on a scanning electron microscopy study. Bot Mar 32:275-298

Dodge JD, Saunders RD (1985) A SEM study of Amphidoma nucula (Dinophyceae) and description of the thecal plates in A. caudata. Arch Protistenkd 129:89-99

Doyle JJ, Doyle JL (1987) A rapid DNA isolation procedure for small quantities of fresh leaf tissue. Phytochem Bull 19:11-15

Fritz L, Triemer RE (1985) A rapid simple technique utilizing Calcofluor white M2R for the visualization of dinoflagellate thecal plates. J Phycol 21:662-664

Gu H, Luo Z, Krock B, Witt M, Tillmann U (2013b) Morphology, phylogeny and azaspiracid profile of Azadinium poporum (Dinophyceae) from the China Sea. Hamful Algae 21-22:64-75

Gu H, Kirsch M, Zinßmeister C, Soehner S, Meier KJS, Liu T, Gottschling M (2013a) Waking the dead: Morphological and molecular characterization of extant $†$ Posoniella tricarinelloides (Thoracosphaeraceae, Dinophyceae). Protist 164:583-597

Hansen G, Moestrup Ø, Roberts KR (1996/97) Light and electron microscopical observations on Protoceratium reticulatum (Dinophyceae). Arch Protistenkd 147:381391

Hernández-Becerril DU, Barón-Campis SA, Escobar-Morales S (2012) A new record of Azadinium spinosum (Dinoflagellata) from the tropical Mexican Pacific. Revista de Biología Marina y Oceanografía 47:553-557

Holmes RW (1956) The annual cycle of phytoplankton in the Labrador Sea, 1950-1951. Bull Bingham Oceanogr Collect 16:1-74

James KJ, Furey A, Lehane M, Ramstad H, Aune T, Hovgaard P, Morris P, Higman W, Satake M, Yasumoto T (2002) First evidence of an extensive northern European distribution of azaspirazid poisoning (AZP) toxins in shellfish. Toxicon 40:909-915

Jauffrais T, Séchet V, Herrenknecht C, Truquet $P$, Veronique S, Tillmann U, Hess $P$ (2013) Effect of environmental and nutritional factors on growth and azaspiracid production of the dinoflagellate Azadinium spinosum Harmful Algae 27:138-148

Keller MD, Selvin RC, Claus W, Guillard RRL (1987) Media for the culture of oceanic ultraphytoplankton. J Phycol 23:633-638

Krock B, Tillmann U, Witt M, Gu H (in press) Azaspiracid variability of Azadinium poporum (Dinophyceae) from the China Sea. Harmful Algae: in press

Krock B, Tillmann U, Voß D, Koch BP, Salas R, Witt M, Potvin E, Jeong HJ (2012) New azaspiracids in Amphidomataceae (Dinophyceae): proposed structures. Toxicon 60:830-839 
López-Rivera A, O'Callaghan K, Moriarty M, O'Driscoll D, Hamilton B, Lehane M, James KJ, Furey A (2009) First evidence of azaspiracids (AZAs): A family of lipophilic polyether marine toxins in scallops (Argopecten purpuratus) and mussels (Mytilus chilensis) collected in two regions of Chile. Toxicon 55:692-701

Luo Z, Gu H, Krock B, Tillmann U (2013) Azadinium dalianense, a new dinoflagellate from the Yellow Sea, China. Phycologia 52:625-636

Nézan E, Tillmann U, Bilien G, Boulben S, Chèze K, Zentz F, Salas R, Chomérat N (2012) Taxonomic revision of the dinoflagellate Amphidoma caudata: transfer to the genus Azadinium (Dinophyceae) and proposal of two varieties, based on morphological and molecular phylogenetic analyses. J Phycol 48:925-939

Okolodkov YB, Dodge JD (1995) Redescription of the planktonic dinoflagellate Peridiniella danica (Paulsen) comb. nov. and its distribution in the N.E. Atlantic. Eur J Phycol 30:299-306

Percopo I, Siano R, Rossi R, Soprano V, Sarno D, Zingone A (2013) A new potentially toxic Azadinium species (Dinophyceae) from the Mediterranean Sea, A. dexteroporum sp. nov. J Phycol 49:950-966

Potvin E, Jeong HJ, Kang NST, Tillmann U, Krock B (2012) First report of the photosynthetic dinoflagellate genus Azadinium in the Pacific Ocean: Morphology and molecular characterizationof Azadinium cf. poporum. J Eukaryot Microbiol 59:145156

Poulin M, Daugbjerg N, Gradinger R, Ilyash L, Ratkova T, von Quillefeldt C (2011) The pan-Arctic biodiversity of marine pelagic and sea-ice unicellular eukaryotes: a firstattempt assessment. Mar Biodivers 41:13-28

Ramsfjell E (1959) Two new phytoplankton species from the Norwegian Sea, the diatom Coscinosira poroseriata, and the dinoflagellate Gonyaulax parva. Nytt Mag Bot 7:175-177

Reinecke P (1967) Gonyaulax grindleyi sp. nov.: a dinoflagelate causing a red tide at Elands Bay, Cape Province, in december 1966. J S Afr Bot 33:157-160

Salas R, Tillmann U, John U, Kilcoyne J, Burson A, Cantwell C, Hess P, Jauffrais T, Silke J (2011) The role of Azadinium spinosum (Dinophyceae) in the production of Azasdpiracid Shellfish Poisoning in mussels. Harmful Algae 10:774-783

Satake M, Ofuji K, James K, Furey A, Yasumoto T (1998) New Toxic Events Caused by Irish Mussels. In Reguera B, Blanco J, Fernandez ML, Wyatt T (eds) Harmful Algae. Xunta de Galicia and Interantional Oceanographic Commission of UNESCO, Santiago de Compostela, pp 468-469

Schiller J (1935) Dinoflagellatae (Peridineae) in monographischer Behandlung. In Rabenhorst L, (ed) Dr. L. Rabenhorst's Kryptogamen-Flora von Deutschland, Österreich und der Schweiz. pp 161-320

Schnepf E, Elbrächter M (1999) Dinophyte chloroplasts and phylogeny - A review. Grana 38:81-97

Taleb H, Vale P, Amanhir R, Benhadouch A, Sagou R, Chafik A (2006) First detection of azaspirazids in mussels in north west Africa. J Shellfish Res 25:1067-1070

Tillmann U, Elbrächter M (2010) Plate Overlap Pattern of Azadinium spinosum Elbrächter et Tillmann (Dinophyceae), the Newly Discovered Primary Source of Azaspiracid Toxins. In Ho KC, Zhou MJ, Qi YZ, (eds) Proceedings of the 13th International Conference on Harmful Algae. Environmental Publication house, Hong Kong, pp 4244

Tillmann U, Taylor B, Krock B (2014b) Azadinium caudatum var. margalefii, a poorly known member of the dinophycean genus Azadinium, a source of azaspiracid toxins. Mar Biol Res: in press 
Tillmann U, Elbrächter M, John U, Krock B (2011) A new non-toxic species in the dinoflagellate genus Azadinium: A. poporum sp. nov. Eur J Phycol 46:74-87

Tillmann U, Soehner S, Nézan E, Krock B (2012b) First record of Azadinium from the Shetland Islands including the description of A. polongum sp. nov. Harmful Algae 20:142-155

Tillmann U, Elbrächter M, John U, Krock B, Cembella A (2010) Azadinium obesum (Dinophyceae), a new nontoxic species in the genus that can produce azaspiracid toxins. Phycologia 49:169-182

Tillmann U, Elbrächter M, Krock B, John U, Cembella A (2009) Azadinium spinosum gen. et sp. nov. (Dinophyceae) identified as a primary producer of azaspiracid toxins. Eur J Phycol 44:63-79

Tillmann U, Salas R, Jauffrais T, Hess P, Silke J (2014a) Azaspiracids. The Producing Organisms: Biology and Food Web Ttransfer. In Botana LM, (ed) Seafood and Freshwater Toxins. CRC Press, Boca Raton, USA, in press

Tillmann U, Salas R, Gottschling M, Krock B, O’Driscoll D, Elbrächter M (2012a) Amphidoma languida sp. nov. (Dinophyceae) reveals a close relationship between Amphidoma and Azadinium. Protist 163:701-719

Toebe K, Joshi AR, Messtorff P, Tillmann U, Cembella A, John U (2013) Molecular discrimination of taxa within the dinoflagellate genus Azadinium, the source of azaspiracid toxins. J Plankton Res 35:225-230

Wołoszyńska HJ (1928) Dinoflagellatae der polnischen Ostsee sowie der an der Piasnica gelegenen Sümpfe. Archiwum Hydrobiologii i Rybactwa 3:155-278

Yao J, Tan Z, Zhou D, Guo M, Xing L, Yang S (2010) Determination of azaspiracid-1 in shellfishes by liquid chromatography with tandem mass spectrometry. Chin J Chrom 28:363-367 


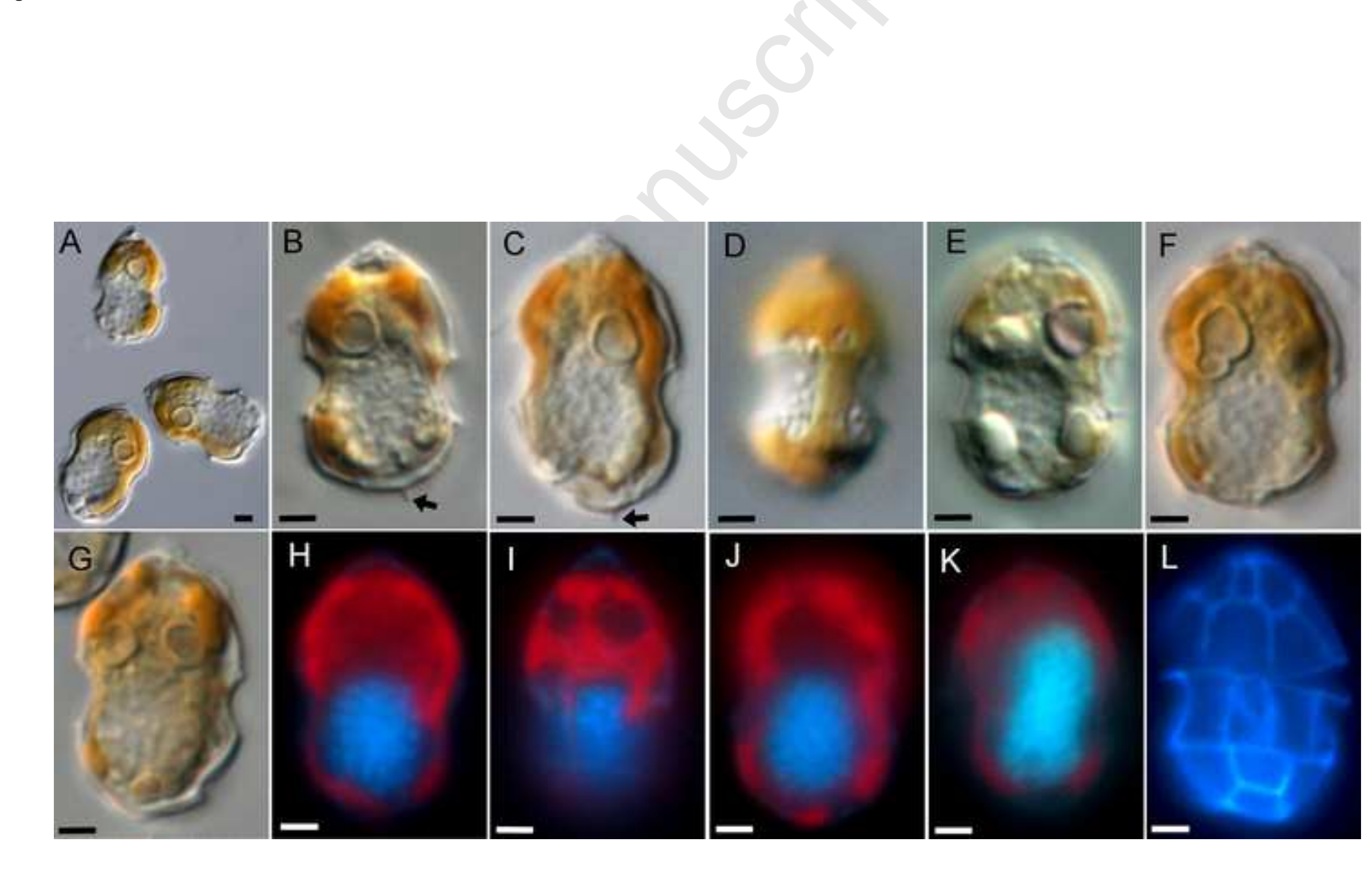

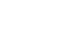
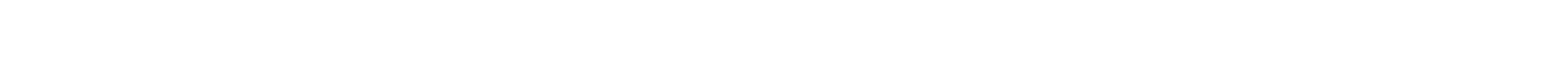

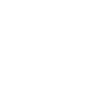

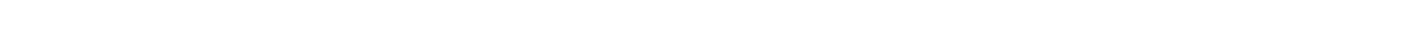



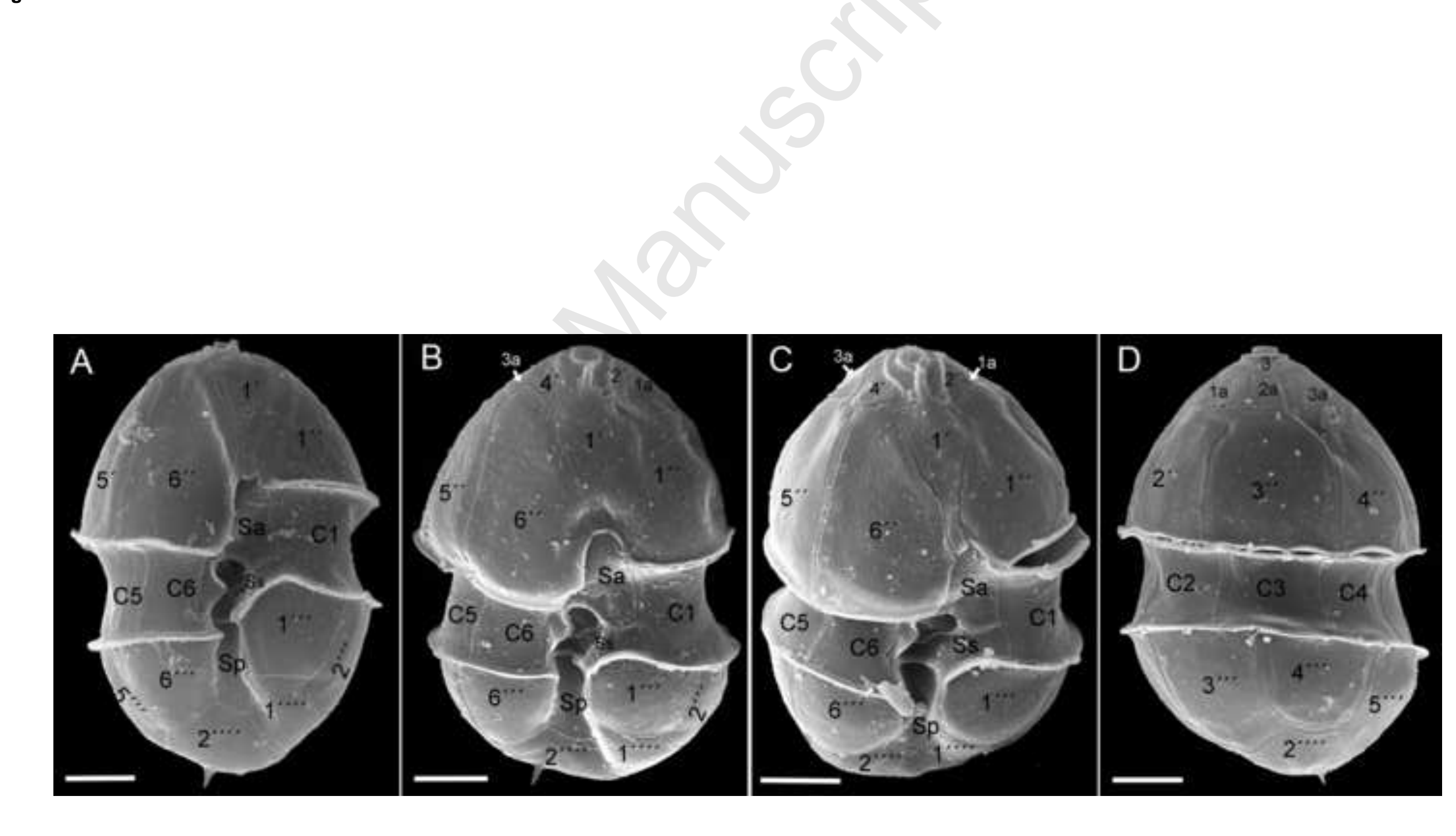

Page 49 of 66

Figure 03

.

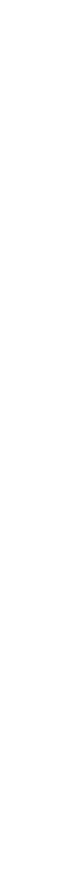

Pld

(
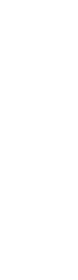

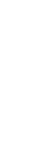

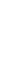

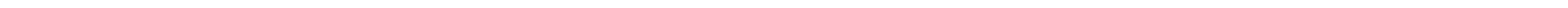



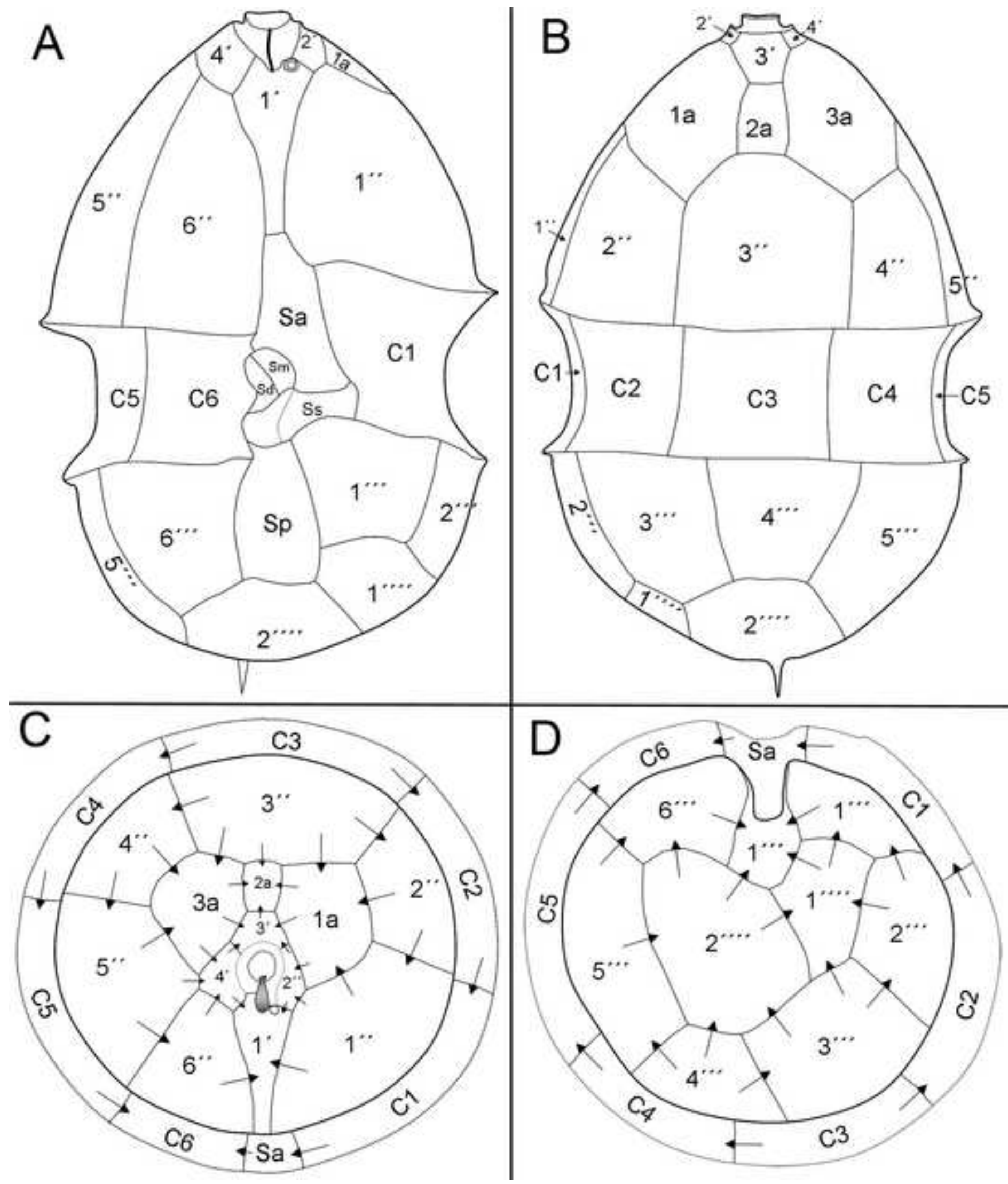

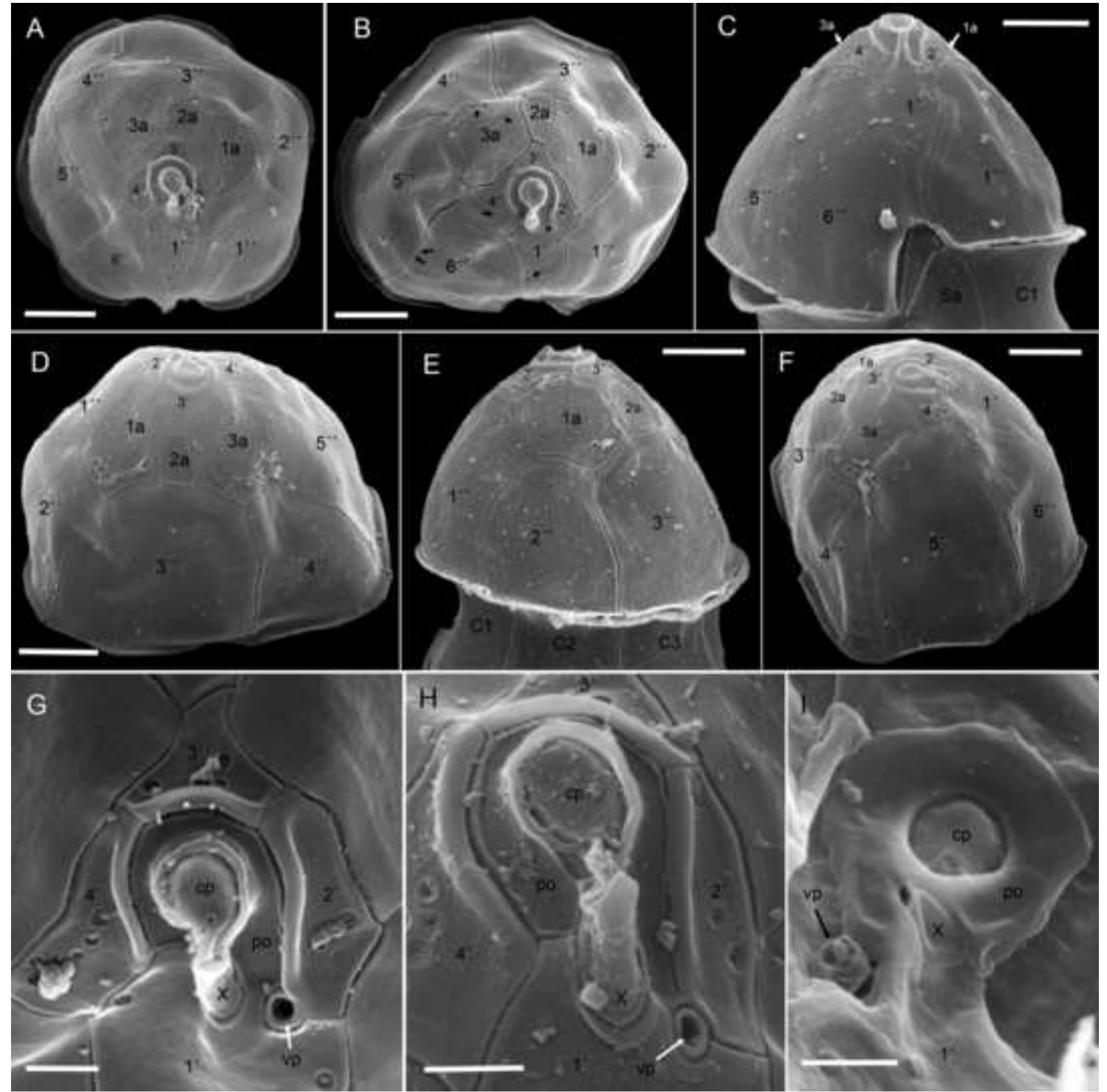

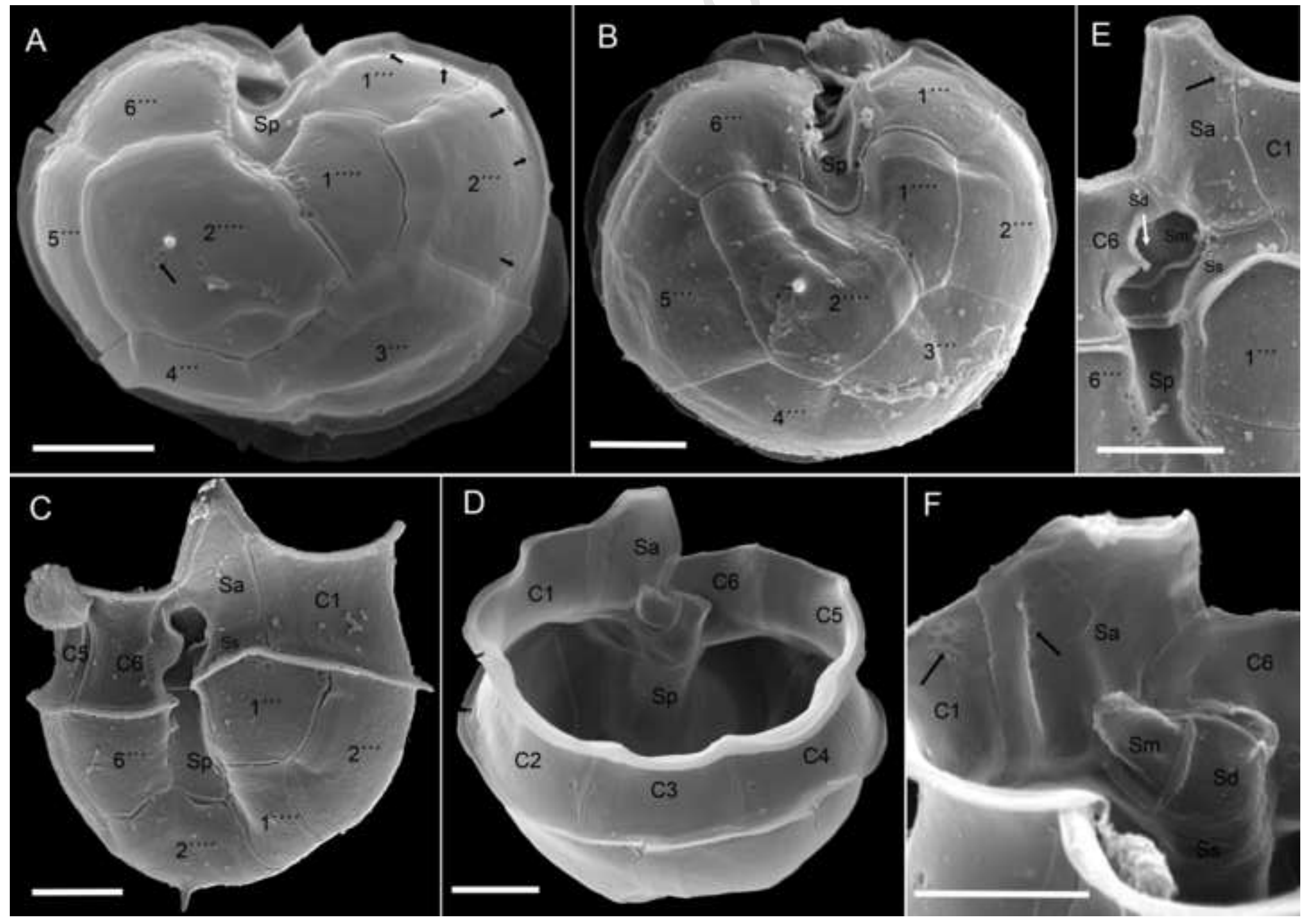

Page 52 of 66 


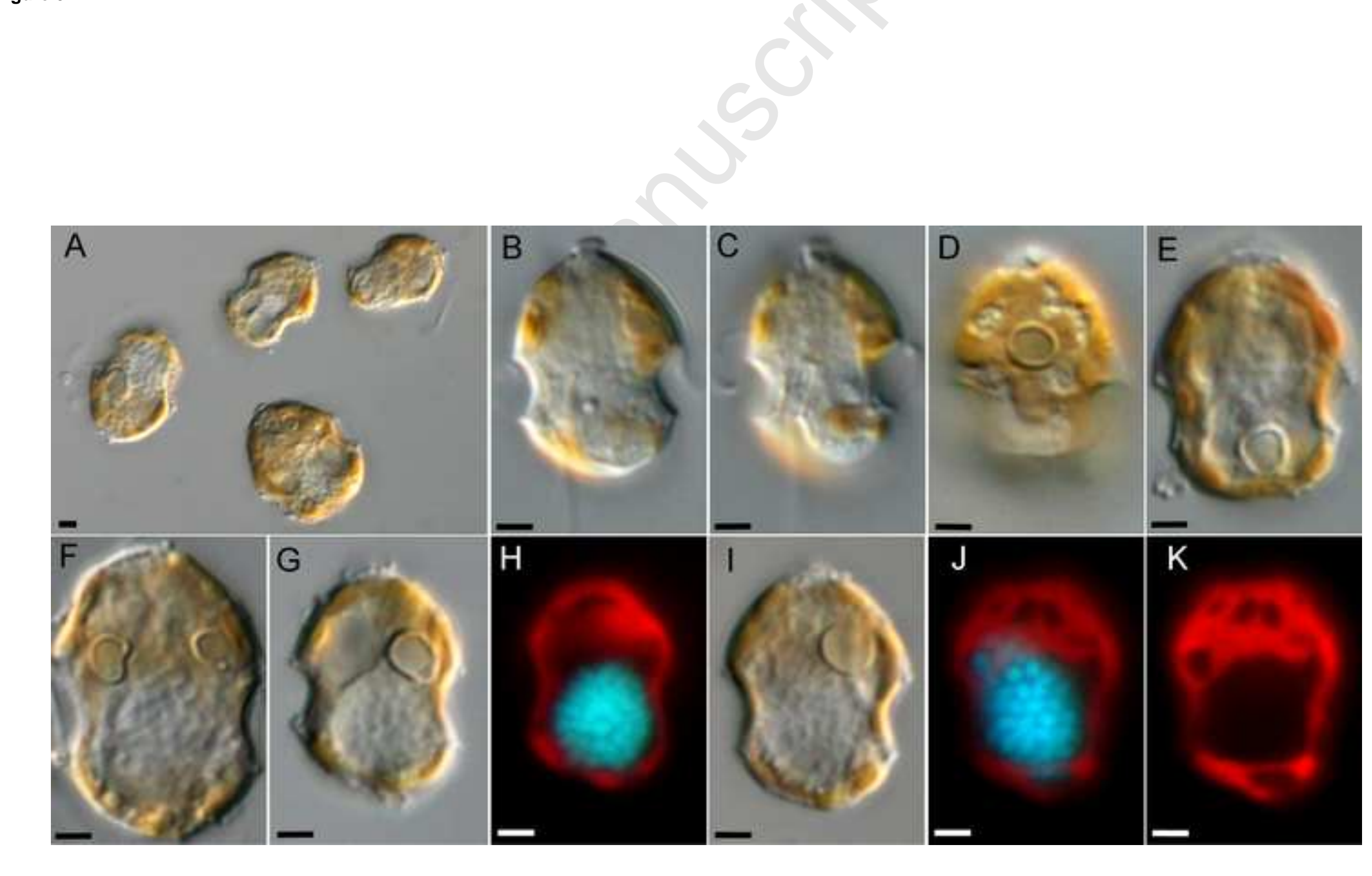

Page

6

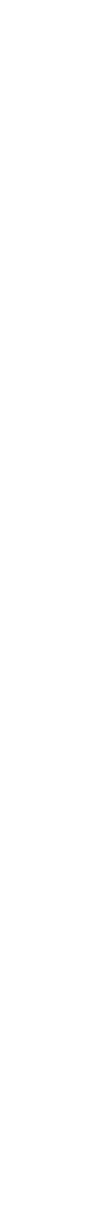



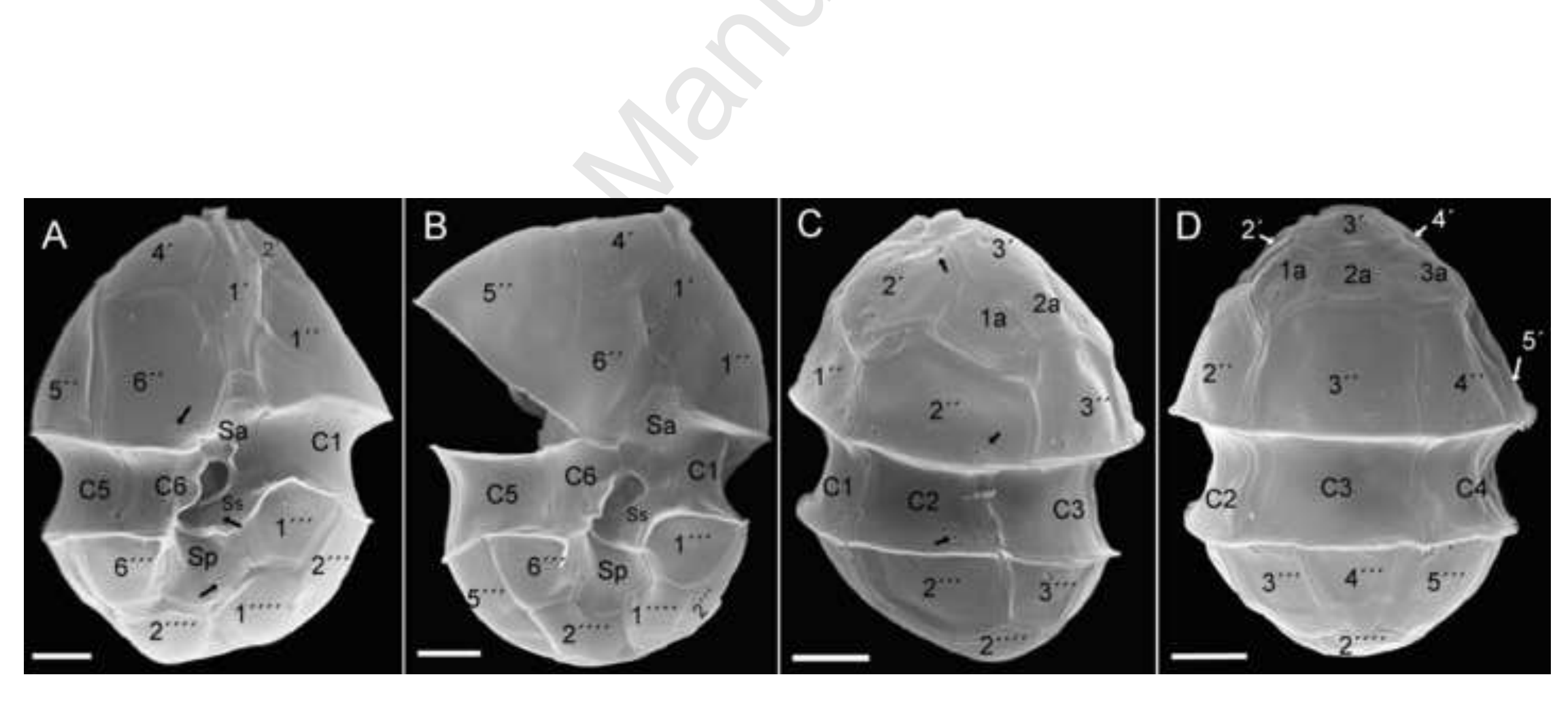

.

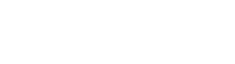



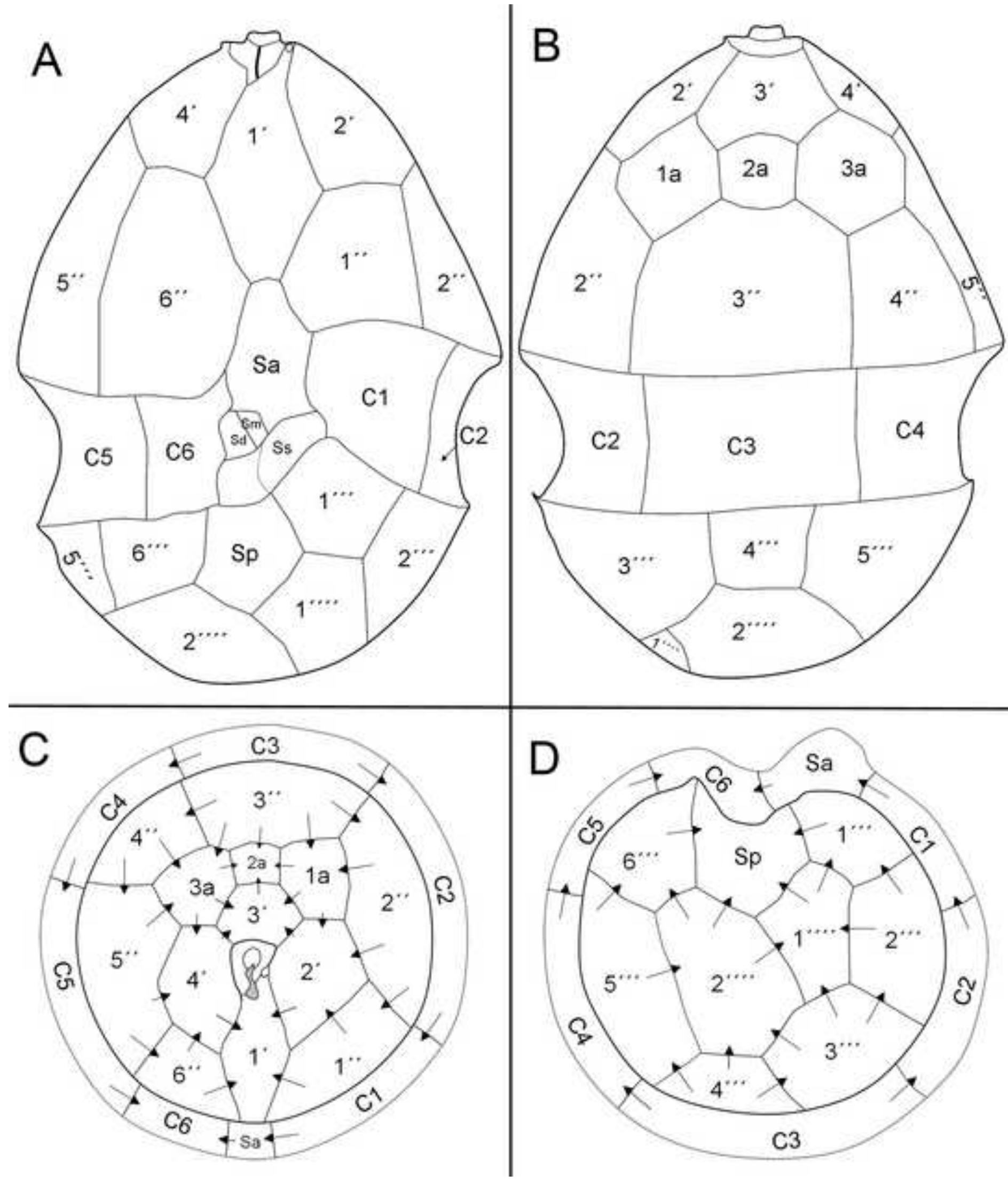


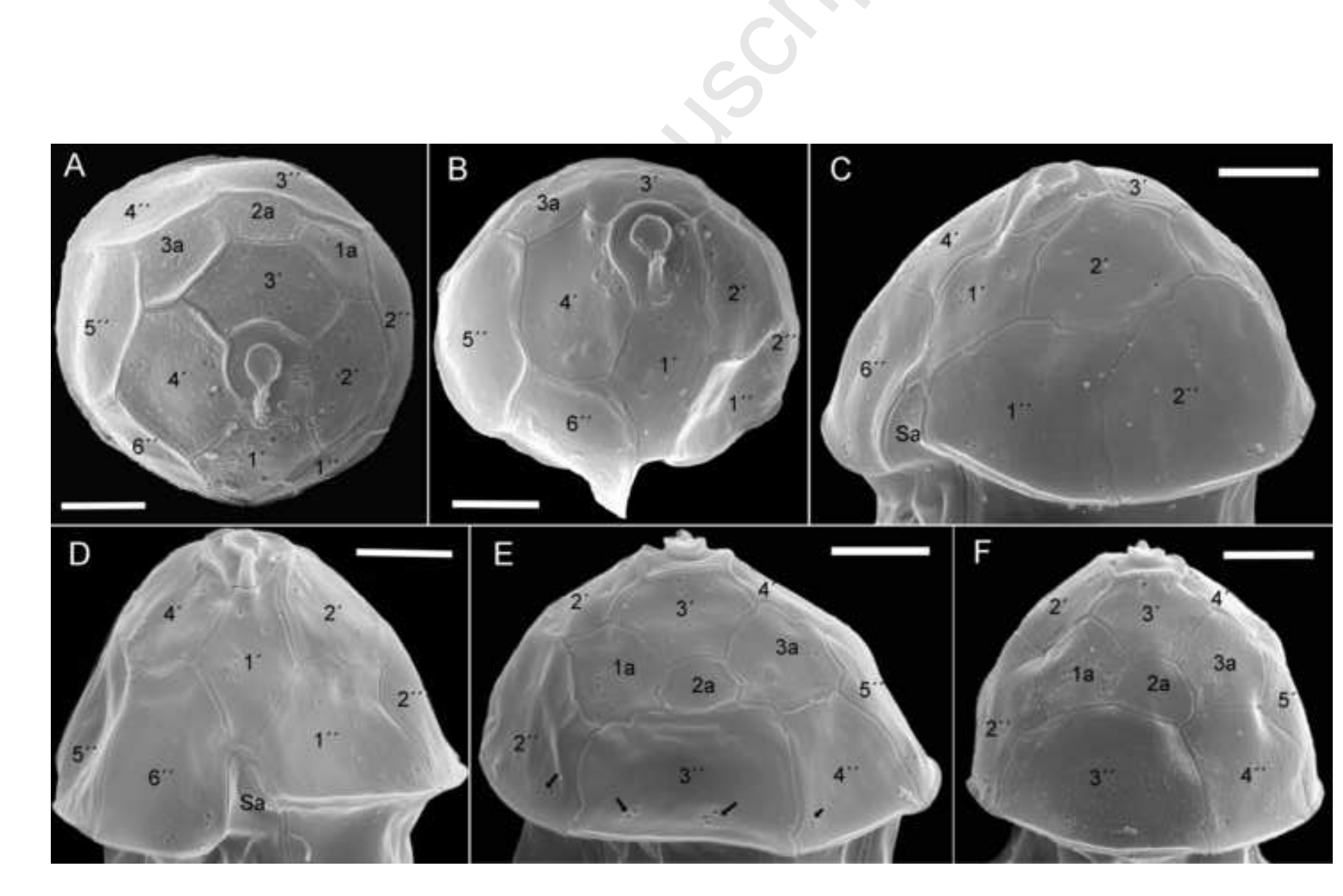

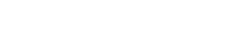

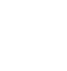




\section{Figure 11}

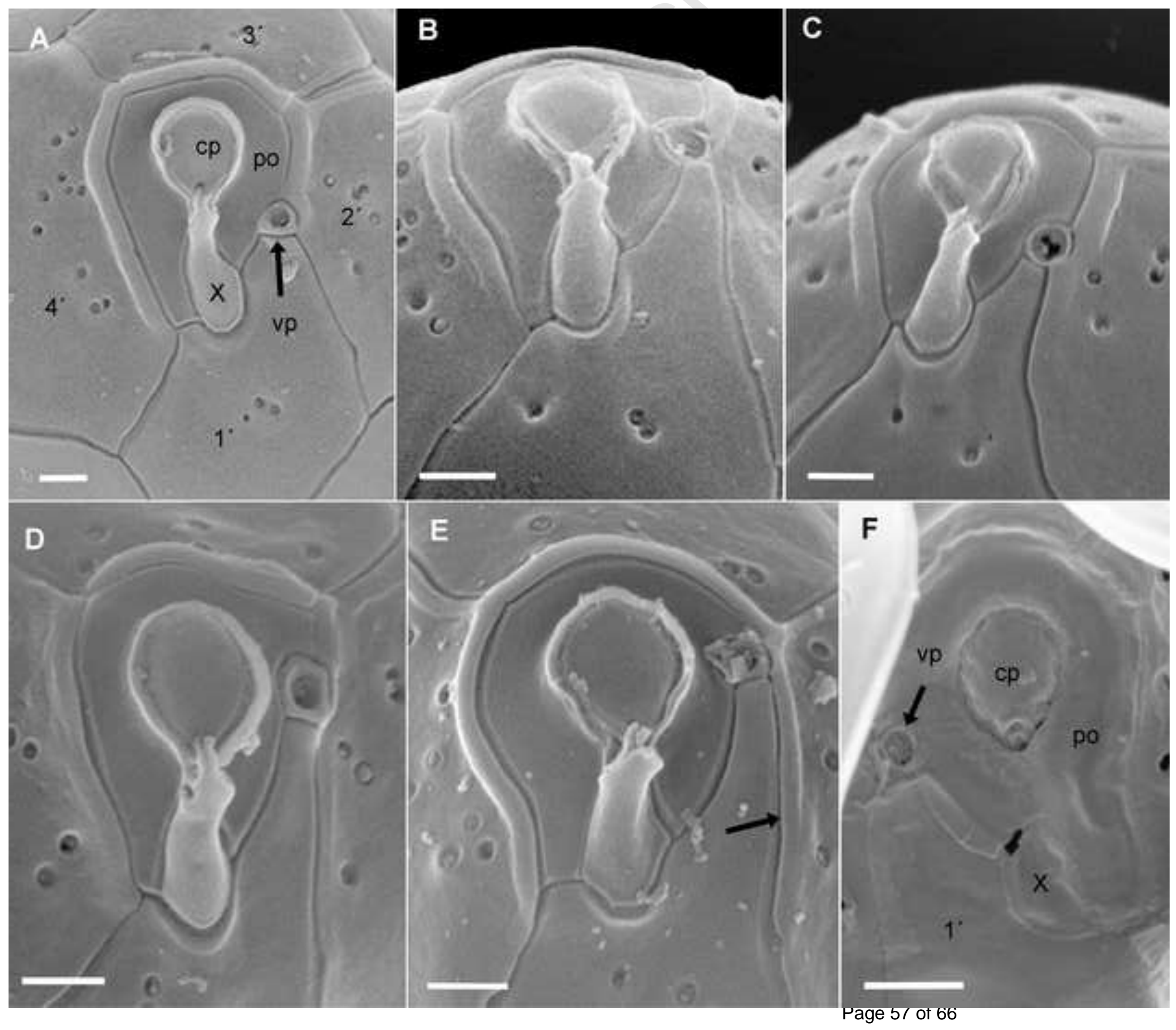



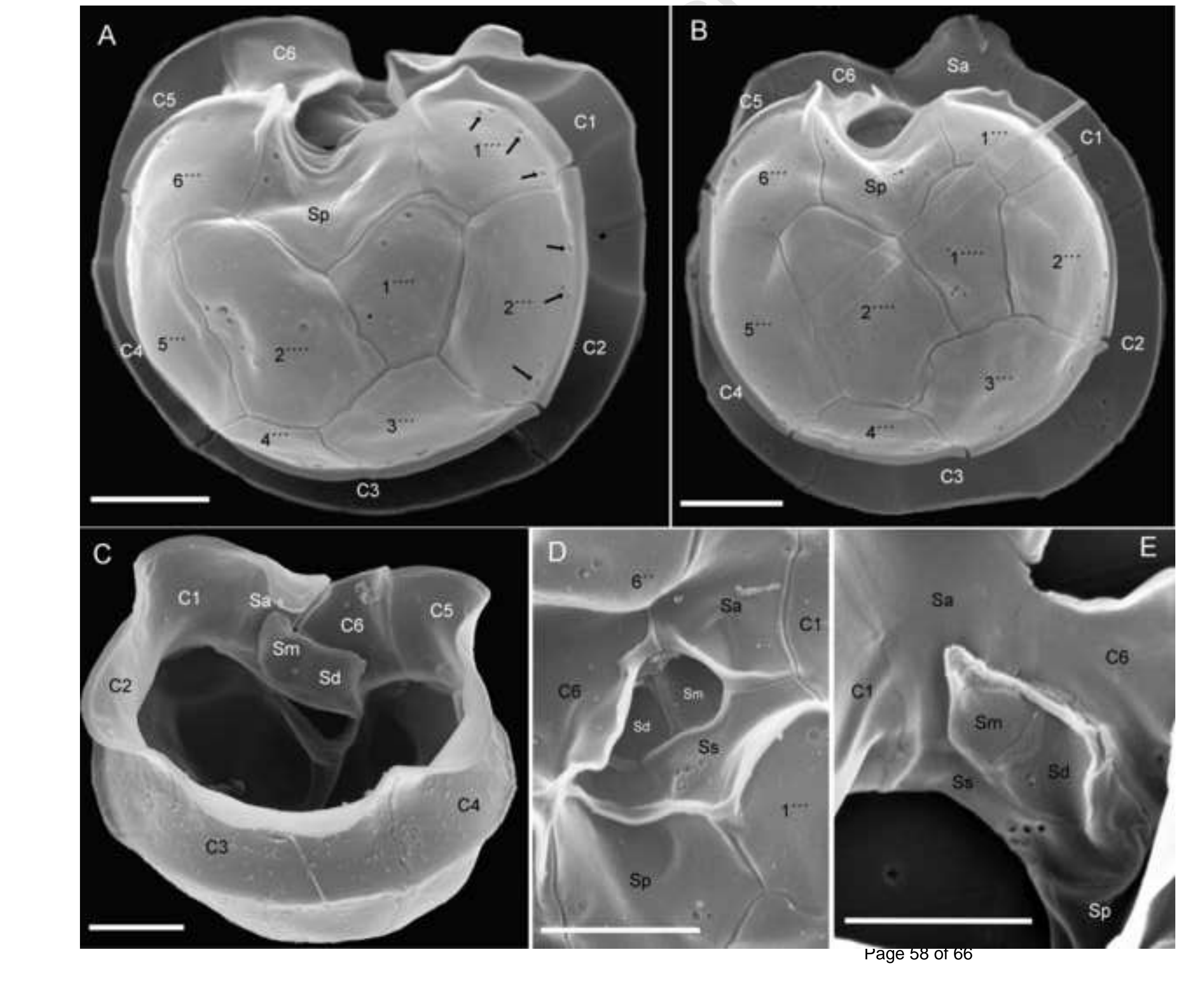

rage 58 of 66 


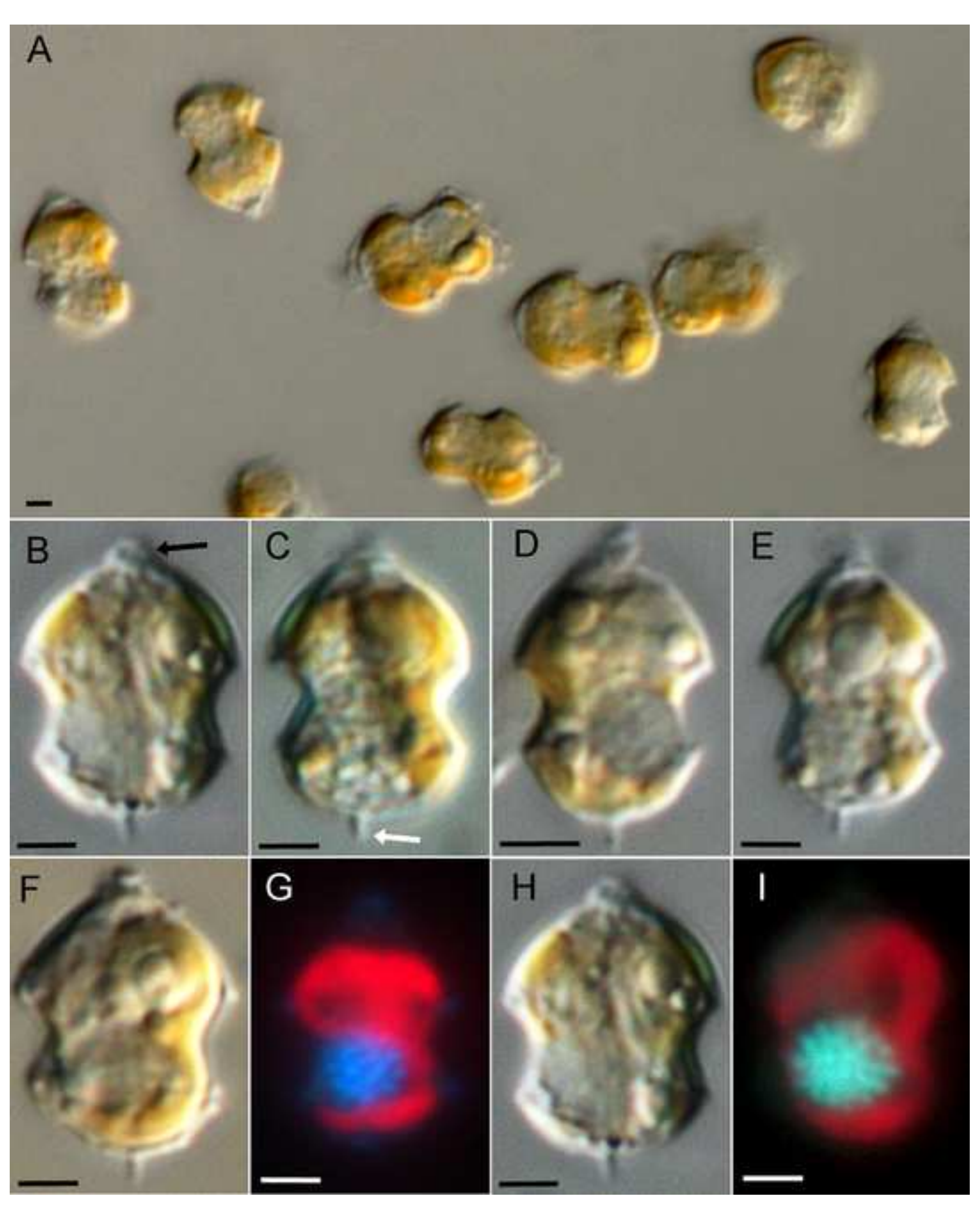

\footnotetext{
Page 59 of 66
}

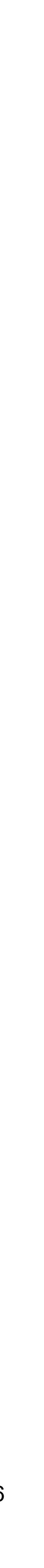


A

5

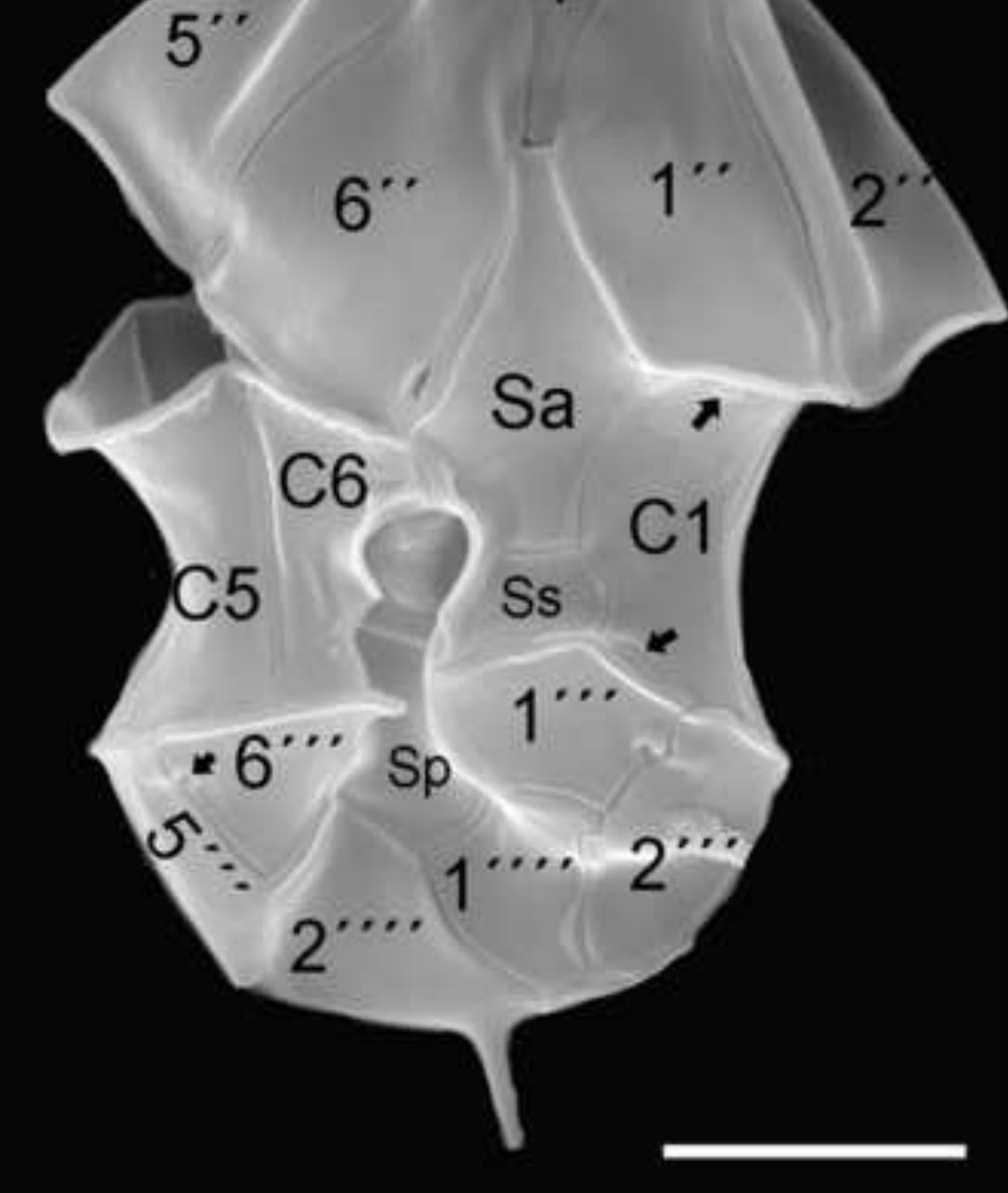

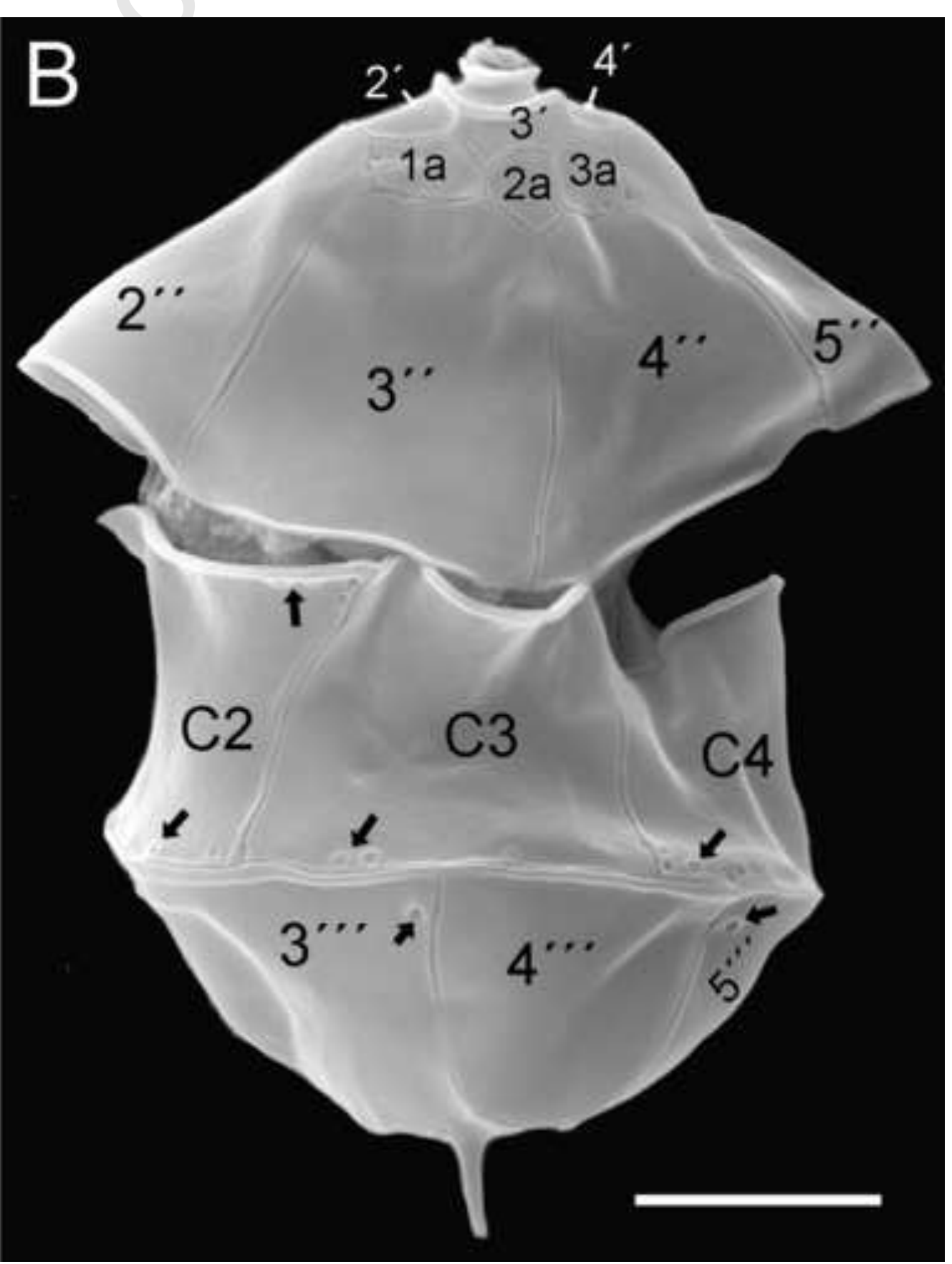

Page 60 of 66 

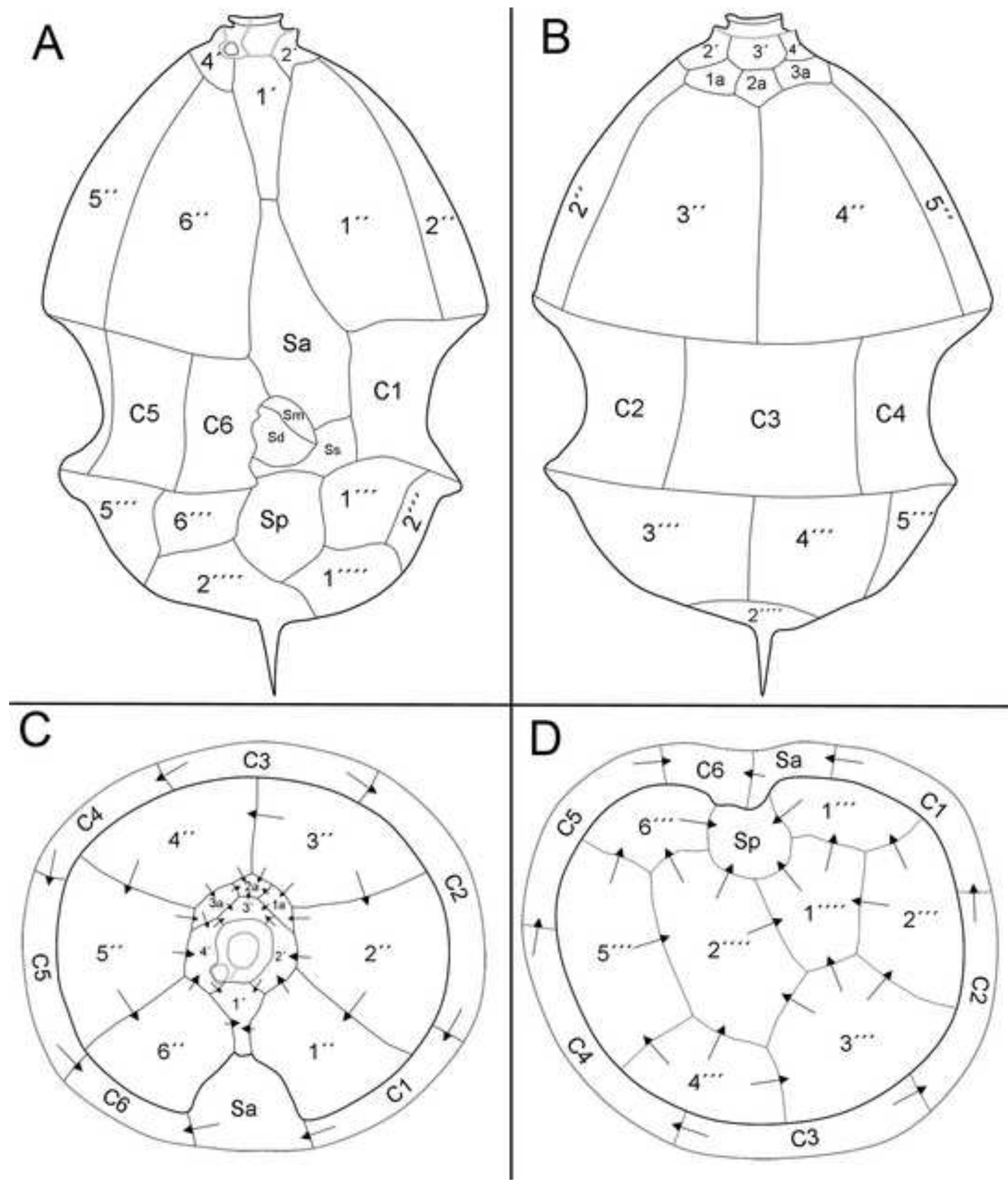

Page 61 of 66 


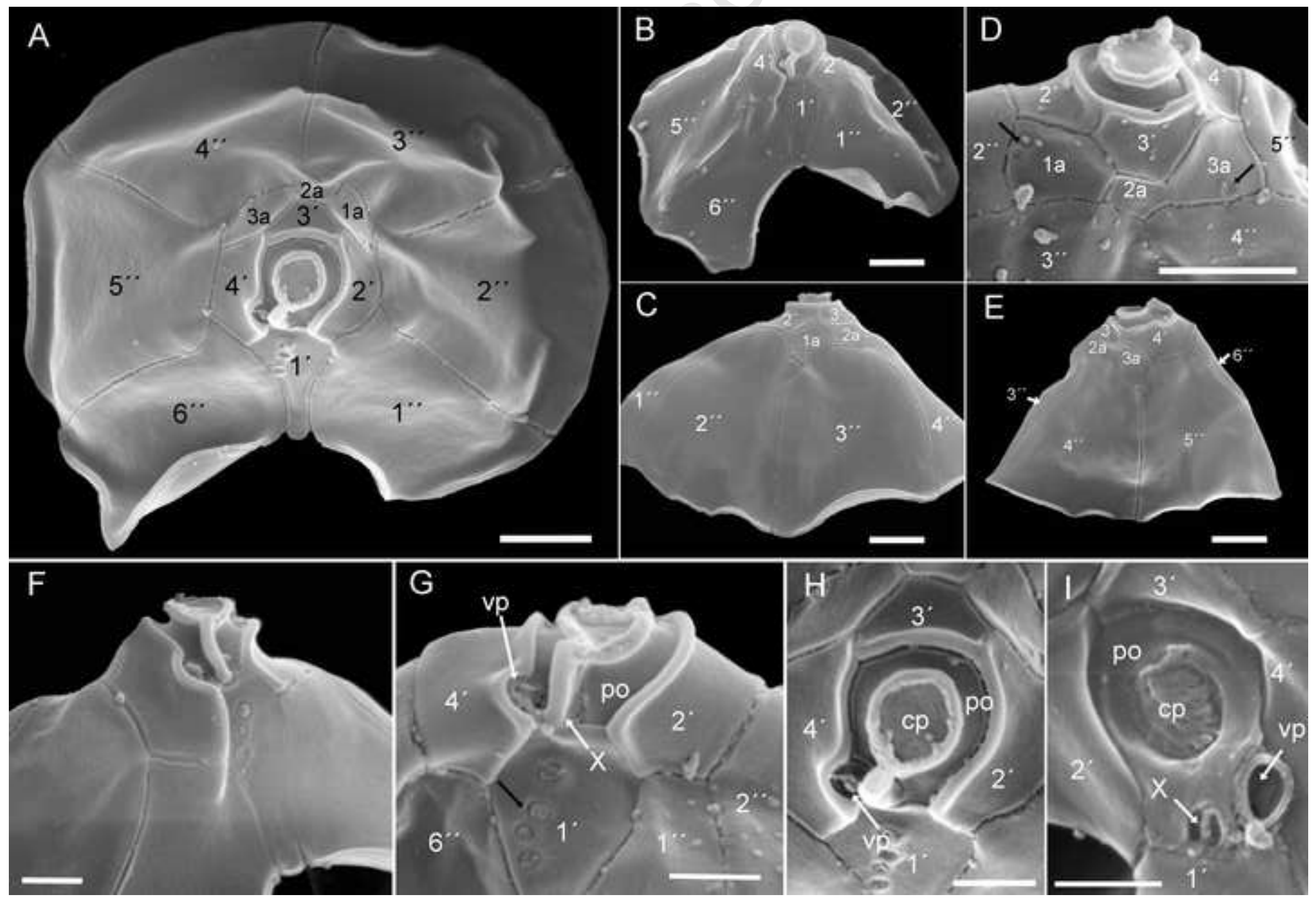

Page 62 of 66 


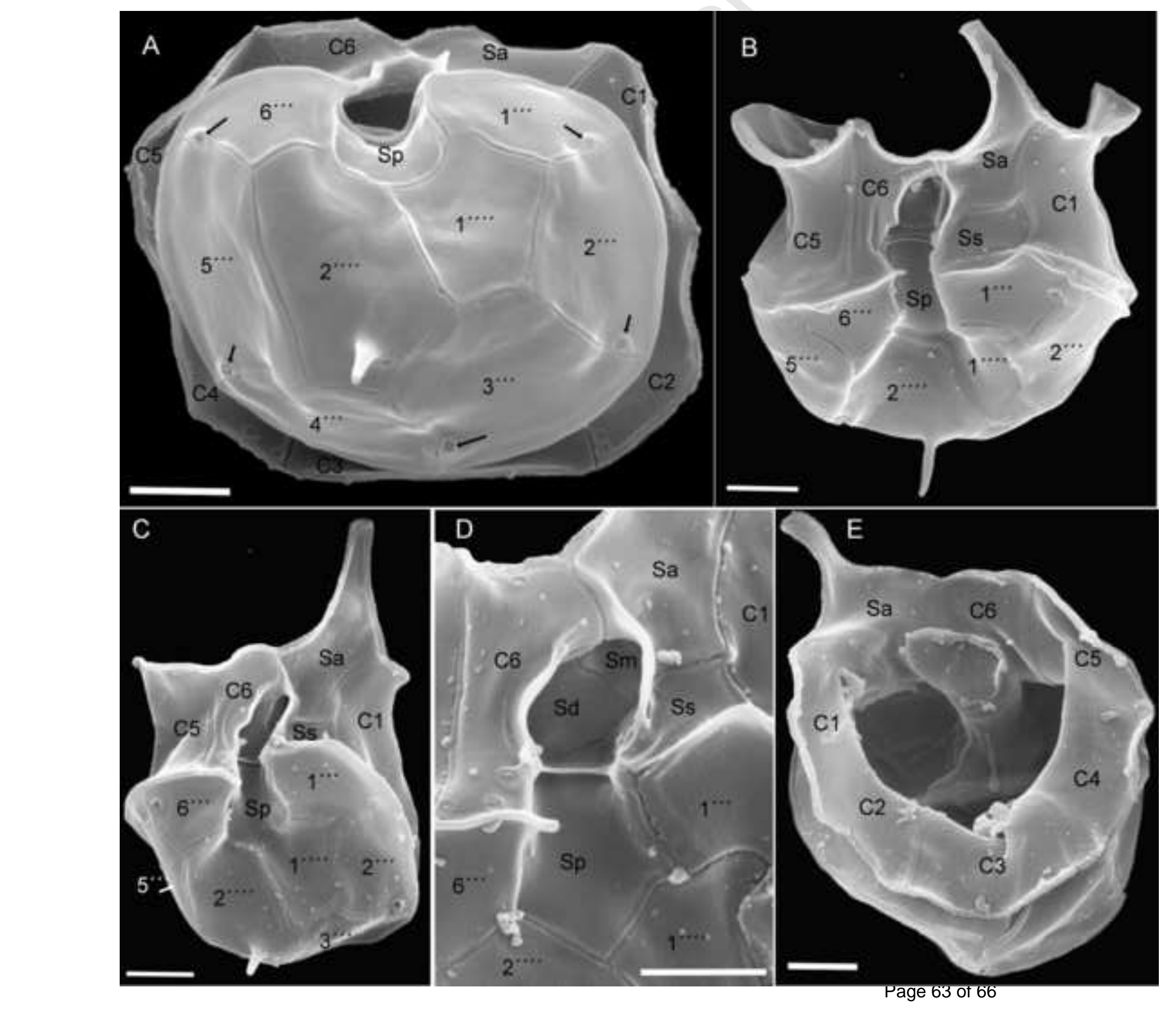

.




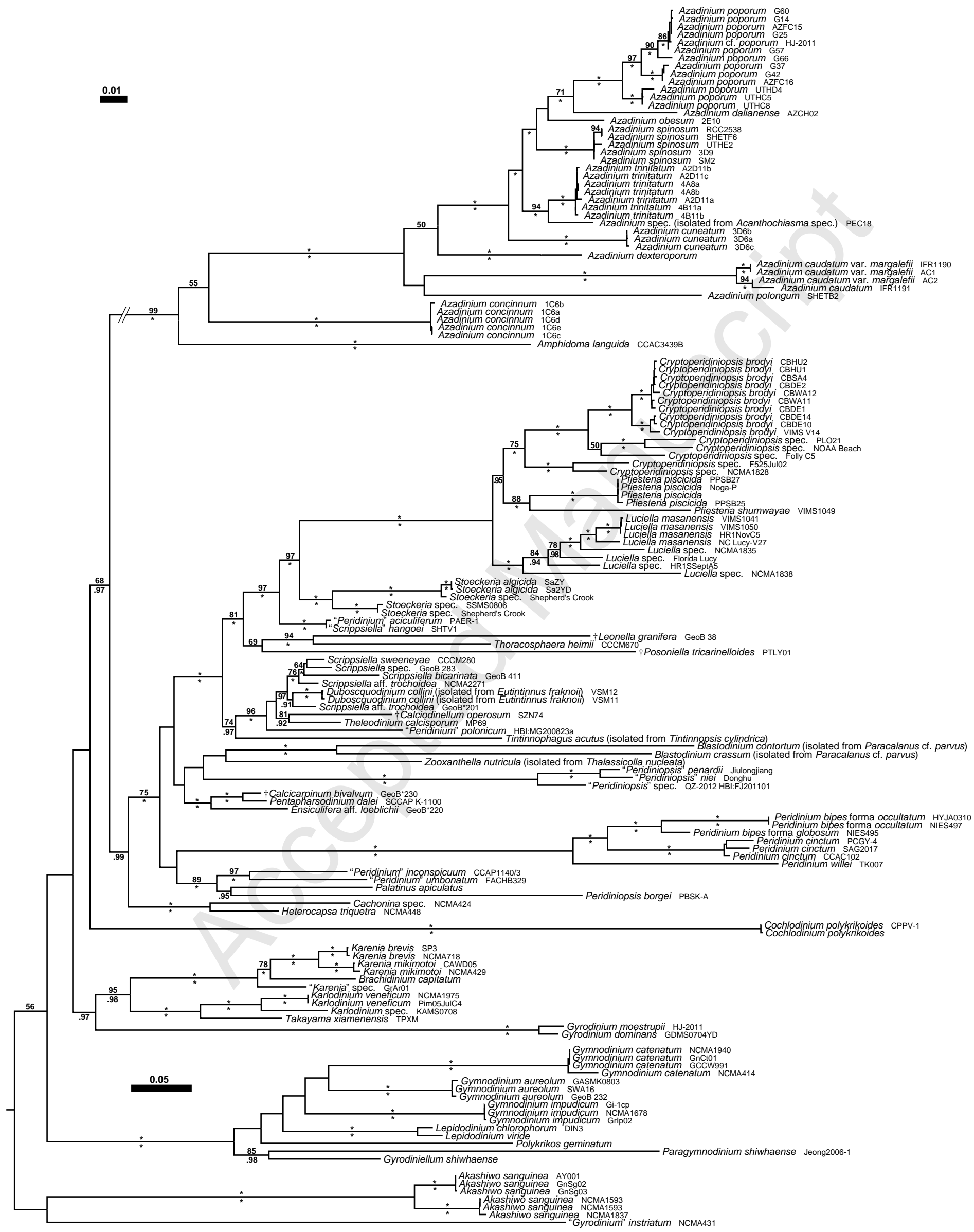



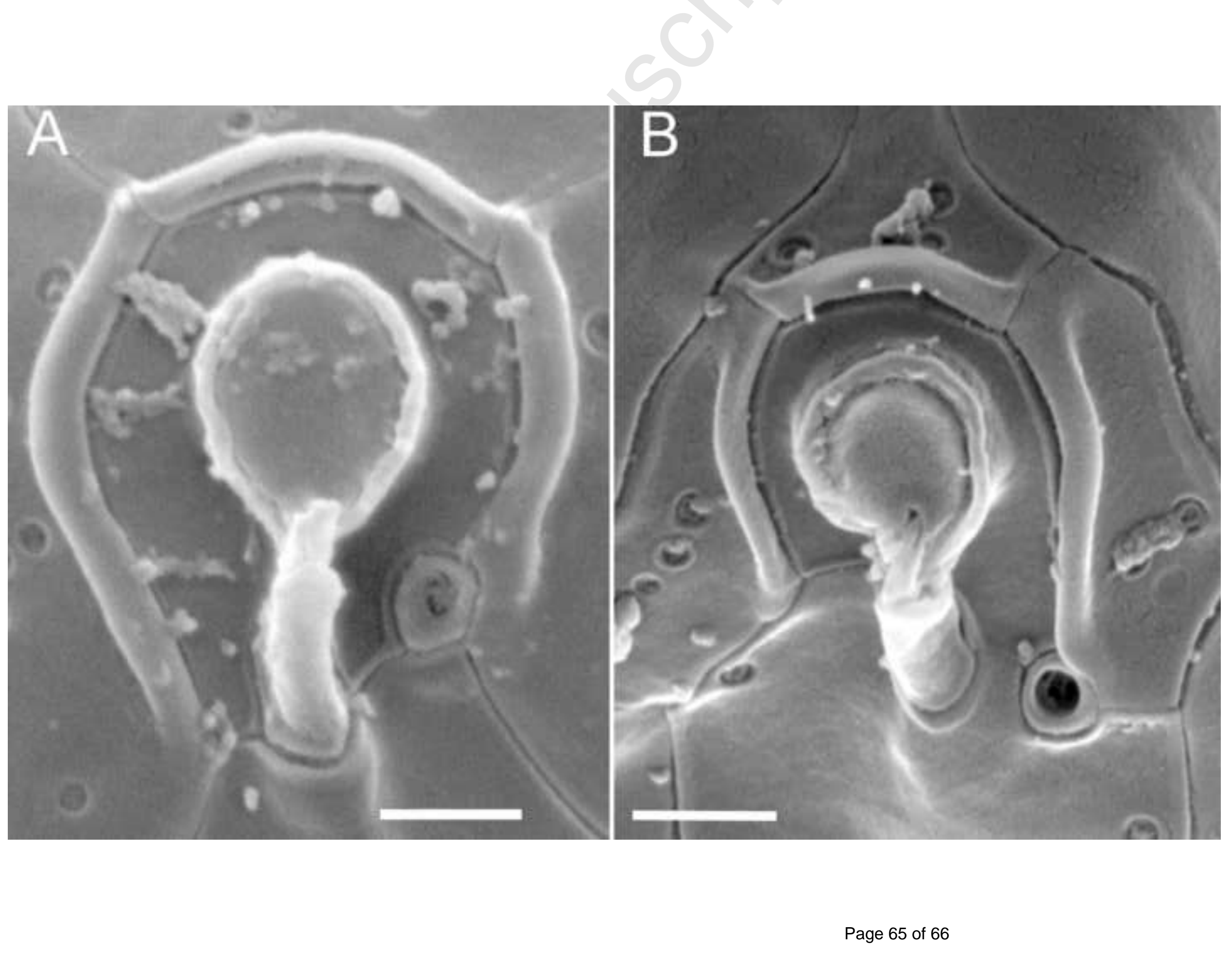

Page 65 of 66

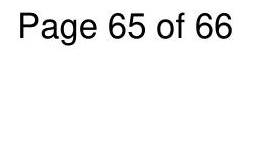

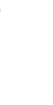

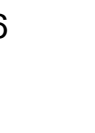
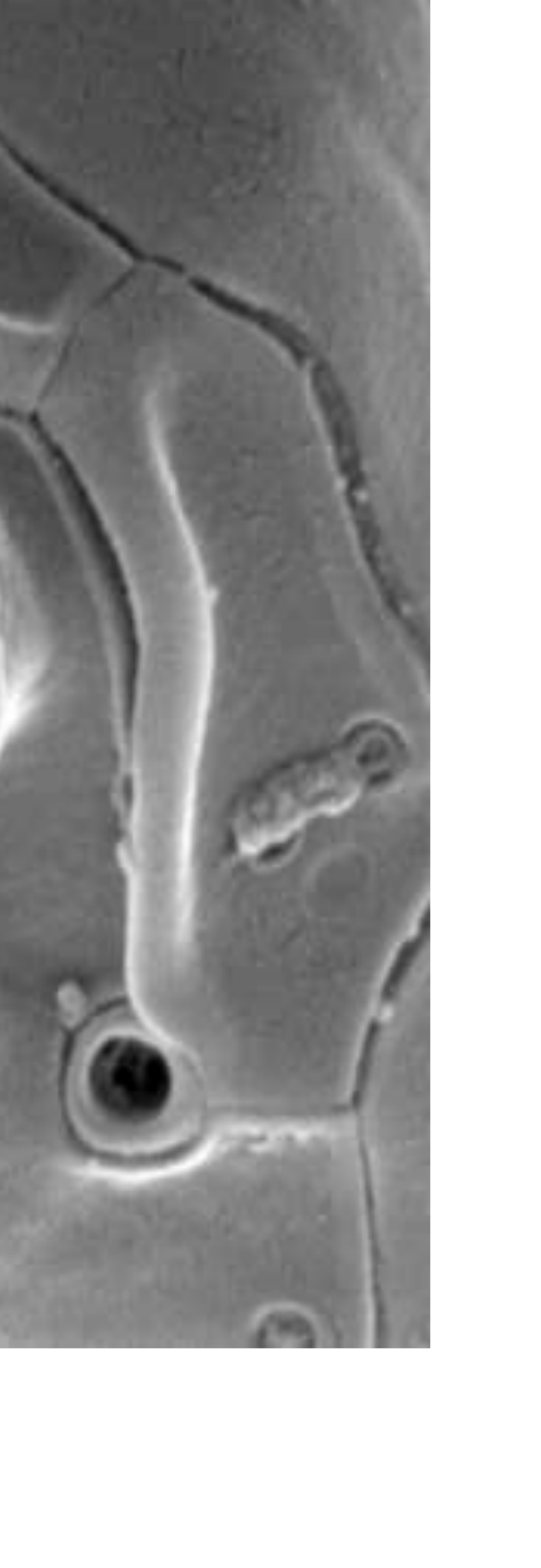


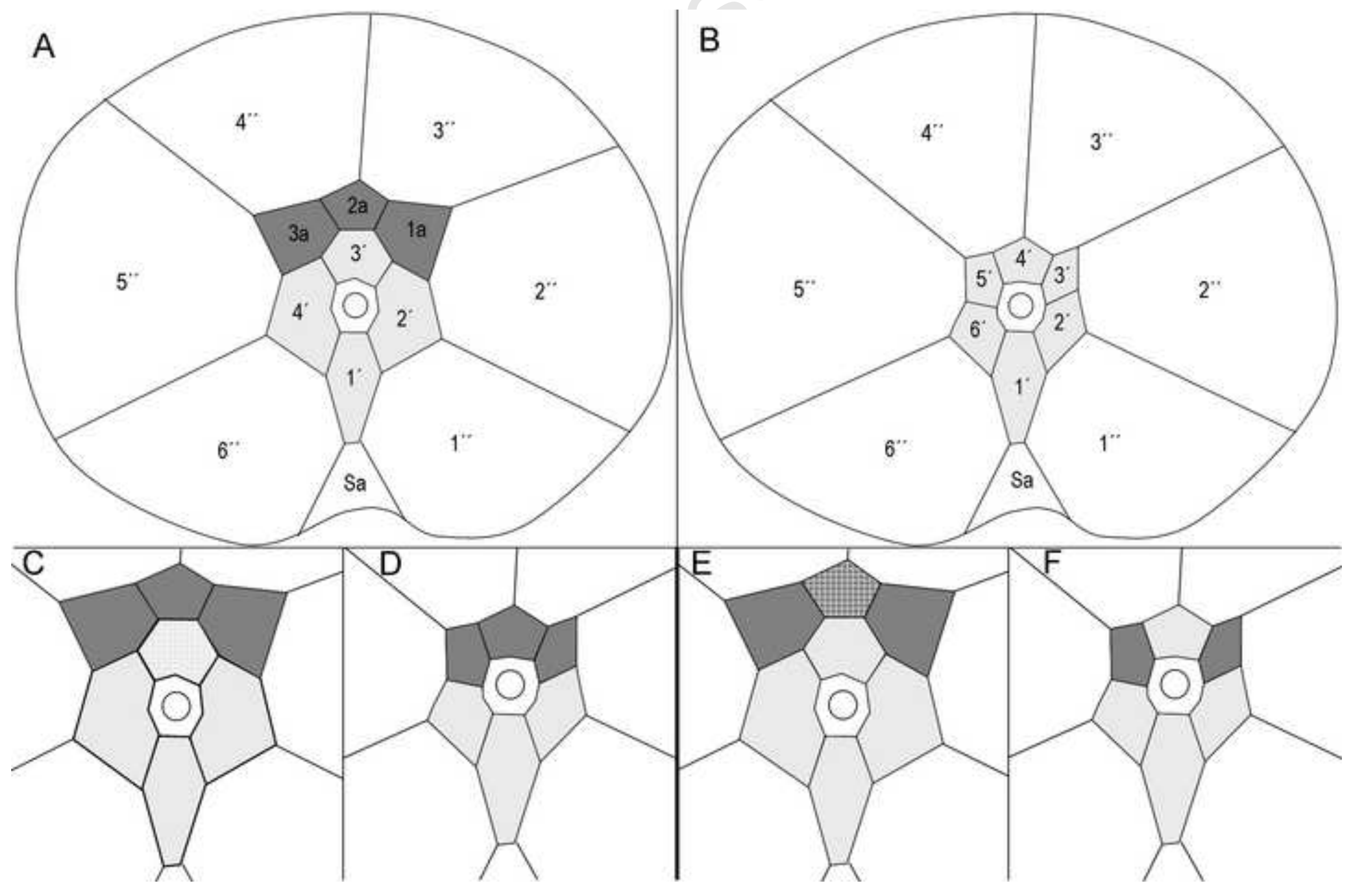

